\title{
Phosphorus Application Improves the Cotton Yield by Enhancing Reproductive Organ Biomass and Nutrient Accumulation in Two Cotton Cultivars with Different Phosphorus Sensitivity
}

\author{
Babar Iqbal ${ }^{1} \mathbb{(}$, Fanxuan Kong ${ }^{1}$, Inam Ullah ${ }^{2}$, Saif Ali ${ }^{1}{ }^{\circledR}$, Huijie Li ${ }^{1}$, Jiawei Wang ${ }^{1}$, \\ Wajid Ali Khattak ${ }^{1}$ and Zhiguo Zhou ${ }^{1, *}$ \\ 1 Key Laboratory of Crop Physiology and Ecology, Ministry of Agriculture, Nanjing Agricultural University, \\ Nanjing 210095, China; agronomist19388@yahoo.com (B.I.); 2017101030@njau.edu.cn (F.K.); \\ saifbhatti63@yahoo.com (S.A.); 2017201013@njau.edu.cn (H.L.); 2017101047@njau.edu.cn (J.W.); \\ wajid_82@ymail.com (W.A.K.) \\ 2 Department of Agronomy, The University of Agriculture Peshawar-Pakistan; Peshawar 25000, Pakistan; \\ inamullah72@yahoo.com \\ * Correspondence: giscott@njau.edu.cn; Tel.: +86-25-84396813; Fax: +86-25-84396813
}

Received: 30 November 2019; Accepted: 14 January 2020; Published: 21 January 2020

\begin{abstract}
Phosphorus (P) plays a pivotal role in cotton by enhancing the reproductive growth and yield formation. Cotton cultivars vary greatly in response to $P$ availability, especially under P-deficient conditions. So, we hypothesized that the increasing $\mathrm{P}$ level promotes the reproductive growth in cotton cultivars varying with P sensitivity. For this, two cotton cultivars, Lu-54 (sensitive to low P) and Yuzaomian-9110 (tolerant to low P), in response to three different P levels (P0: 0 (control), P1: 100, and P2: $200 \mathrm{~kg} \mathrm{P}_{2} \mathrm{O}_{5} \mathrm{ha}^{-1}$ ) were studied at 39, 52, 69, 83, and 99 days after transplanting during 2017 and 2018. The results revealed that the seed cotton yield was improved in P1 and P2 treatments by $23.9 \%-34.5 \%$ and $30.8 \%-52.3 \%$ in Lu- 54 , and $16.6 \%-25.6 \%$ and $20.6 \%-38.5 \%$ in Yuzaomian- 9110 during 2017 and 2018, respectively. The accumulation of reproductive organ biomass was $21.0 \%-52.1 \%$ and $28.5 \%-56.8 \%$ higher in Lu-54 and $24.2 \%-56.8 \%$ and $34.8 \%-69.1 \%$ higher in Yuzaomian-9110 in P1 and P2 over the control, respectively. During the fast accumulation period, the average accumulation of $\mathrm{N}, \mathrm{P}, \mathrm{K}$, and biomass across the years in P2 were recorded as $0.75,0.6,0.5$, and $120.5 \mathrm{~kg} \mathrm{ha}^{-1} \mathrm{~d}^{-1}$ in Lu-54, while they were $0.65,0.5,0.8$, and $98.5 \mathrm{~kg} \mathrm{ha}^{-1} \mathrm{~d}^{-1}$ in Yuzaomian-9110. Overall, a longer period, in terms of reproductive biomass accumulation, was recorded for Yuzaomian-9110 compared with Lu-54 in 2017 and vice versa across the 2018 growing season. The results suggested that increasing P rate improved yield, reproductive organ biomass, as well as nutrient accumulation in both cotton cultivars. However, low P-sensitive cultivar (Lu-54) was more responsive to $\mathrm{P}$ application compared with low P-tolerant cultivar.
\end{abstract}

Keywords: cotton; phosphorus sensitivity; phosphorus; reproductive organ biomass; nutrients accumulation; yield

\section{Introduction}

Cotton (Gossypium hirsutum L.) is globally considered as one of the most important commercial crops. Being a cash crop, it is grown worldwide for the purpose of oil, lint, and feed for animals [1]. About 30 million hectares of fertile land is engaged in cotton cultivation in almost 70 different countries of the world [2]. China is the world's largest cotton producer and consumer [3,4], with an average lint yield of $14.38 \mathrm{~g} \mathrm{~m}^{-2}$ during 2013 followed by the US, India, and Pakistan [5]. Due to its indeterminate 
growth habit, cotton exhibits morphological adaptation, such as modifying the canopy arrangement with phosphorus $(\mathrm{P})$ application [6]. The morphological adaptations in terms of light capture, sink to source relationship, and photoassimilates distribution, are the main reasons of enhancing seed cotton yield $[7,8]$. For the last two decades, cotton yield per unit area remained stagnant in spite of the introduction of new high yielding cultivars $[7,8]$. Utilization of mineral fertilizers is sought as an effective strategy to improve soil nutrient and boost cotton yield.

The use of increased fertilization has influenced the crop production over the last several years because of its effect on soil nutritional status and fertility characteristics [9]. Phosphate fertilizer is central to crop productivity with a higher $\mathrm{P}$ requirement that is not in competition with soil $\mathrm{P}$, especially at sub-optimal level compared with other nutrients [10]. Phosphorus is very important in crop production after nitrogen $(\mathrm{N})$; however, its resources are limited worldwide [11]. The $\mathrm{P}$ application improves root architecture by increasing length, width, and diameter of root. Hence, P uptake by the plants is predominantly controlled by the availability and acquisition of $\mathrm{P}$ [12-14]. Therefore, the P deficiency inhibits cotton growth and development by declining the biomass accumulation, leading to lower seed cotton yield [15].

Crop growth requires nutrients' availability and constant supply throughout the growing season. Cotton yield responds positively to the availability of the nutrients, especially P [16]. The availability of $P$ in the soil affects the nutrient accumulation and dry matter accumulation in the cotton plant parts [17]. The existence of varietal differences also fluctuated the accumulation of nutrient and biomass with greater tendency towards the vegetative organ [18]. Improving the cotton cultivars with better nutrient management to obtain higher economic yield is of great importance to minimize the environmental impact of inorganic fertilizers.

The cotton cultivars respond differently to the $\mathrm{P}$ availability and results in the increase of seed cotton yield $[19,20]$. Different plant cultivars show genetic diversity in the utilization and absorption of $\mathrm{P}$ ratios. Cotton cultivars showing sensitivity to low $\mathrm{P}$ may increase plant performance by the application of more $\mathrm{P}$ as compared to cultivars with low $\mathrm{P}$ tolerance [21]. The stunted growth and low yield resulted by $\mathrm{P}$ deficits in cotton [16] have been reported, but data regarding cotton cultivars with different $P$ sensitivity under different $P$ rates are still lacking. Screening and using P-efficient cotton cultivars with better uptake of $\mathrm{P}$ can provide a base to increase $\mathrm{P}$ utilization in plants $[22,23]$. The current study is aimed at evaluating the response of $\mathrm{P}$ application, $\mathrm{P}, \mathrm{N}$, and $\mathrm{K}$ relationship due to $P$ fluctuation, and to estimate P's role in accumulating different nutrients in the reproductive organ (RO) of the plant. The evaluation was carried out at different days after transplanting (DAT) with 39, $52,69,83$, and 99 at Squaring "SQ", first bloom "FB", peak bloom "PB", boll setting "BS", and boll opening "BO" in two different cotton cultivars having different response to inorganic $P$ (i.e., sensitive versus tolerant to low $\mathrm{P}$ ) and different $\mathrm{P}$ rates. The objectives of the present study were to assess the effects of different $\mathrm{P}$ regimes on different $\mathrm{P}$-efficient cotton cultivars in their yield, nutrient, biomass accumulation, and allocation in the RO of cotton.

\section{Materials and Methods}

\subsection{Experimental Site and Field Conditions}

A 2-year field experiment was conducted at Pailou Research Station ( $118^{\circ} 50^{\prime}$ E, $\left.32^{\circ} 02^{\prime} \mathrm{N}\right)$, Nanjing Agricultural University, Jiangsu, P.R. China. The soil of the experimental field was mixed, acidic clay, thermic, and typic Alfisols (Udalfs; FAO Luvisol). The pre-planting soil samples were collected from 0-20 and 20-40 cm depth. Soil properties (Table 1) of the collected samples were determined by following Yang et al. [24]. Weather data of mean monthly air temperature and rainfall during 2017 and 2018 are given in Figure 1. 
Table 1. Soil fertility status of the experimental site during 2017 and 2018 . Data of soil samples collected from topsoil (0-20 cm) and subsoil (20-40 cm) depths before planting.

\begin{tabular}{|c|c|c|c|c|c|c|c|c|c|c|c|c|}
\hline & & $\begin{array}{c}\mathrm{pH} \\
\left(\mathrm{H}_{2} \mathrm{O}\right)\end{array}$ & $\begin{array}{l}\text { Bulk Density } \\
\qquad\left(\mathrm{g} \mathrm{cm}^{3}\right)\end{array}$ & $\begin{array}{c}\mathrm{TN} \\
\left(\mathrm{g} \mathrm{kg}^{-1}\right)\end{array}$ & $\begin{array}{c}\text { EC } \\
\left(\mu \mathrm{cm}^{-1}\right)\end{array}$ & $\begin{array}{c}\mathrm{SOM} \\
\left(\mathrm{g} \mathrm{kg}^{-1}\right)\end{array}$ & $\begin{array}{c}\mathrm{AN} \\
\left(\mathrm{NH}_{4}{ }^{+}\right)\left(\mathrm{mg} \mathrm{kg}^{-1}\right)\end{array}$ & $\begin{array}{c}\mathrm{AN} \\
\left(\mathrm{NO}_{3}{ }^{-1}\right)\left(\mathrm{mg} \mathrm{kg}^{-1}\right)\end{array}$ & $\begin{array}{c}\mathrm{AP} \\
\left(\mathrm{mg} \mathrm{kg}^{-1}\right)\end{array}$ & $\begin{array}{c}\mathrm{AK} \\
\left(\mathrm{mg} \mathrm{kg}^{-1}\right)\end{array}$ & $\begin{array}{c}\mathrm{TP} \\
\left(\mathrm{g} \mathrm{kg}^{-1}\right)\end{array}$ & $\begin{array}{c}\mathrm{TK} \\
\left(\mathrm{g} \mathrm{kg}^{-1}\right)\end{array}$ \\
\hline \multirow[t]{2}{*}{ Year 2017} & $\begin{array}{c}\text { topsoil } \\
(0-20 \mathrm{~cm})\end{array}$ & 6.84 & 1.35 & 1.03 & 170 & 18.0 & 61.21 & 11.32 & 16.91 & 139.4 & 0.61 & 5.81 \\
\hline & $\begin{array}{c}\text { subsoil } \\
(20-40 \mathrm{~cm})\end{array}$ & 7.45 & 1.29 & 0.95 & 185 & 17.7 & 59.32 & 11.21 & 16.72 & 135.6 & 0.48 & 4.87 \\
\hline \multirow{2}{*}{ Year 2018} & $\begin{array}{c}\text { topsoil } \\
(0-20 \mathrm{~cm})\end{array}$ & 6.94 & 1.44 & 1.11 & 183 & 19.1 & 64.92 & 13.91 & 17.85 & 144.3 & 0.69 & 5.87 \\
\hline & $\begin{array}{c}\text { subsoil } \\
(20-40 \mathrm{~cm})\end{array}$ & 7.54 & 1.32 & 1.06 & 190 & 18.4 & 61.01 & 12.1 & 17.02 & 140.6 & 0.52 & 4.21 \\
\hline
\end{tabular}

TN: Total nitrogen; EC: Electrical conductivity; SOM: Soil organic matter; AN: Available nitrogen; AP: Available phosphorus; AK: Available potassium; TP: Total phosphorus; TK: Total potassium. 
rainfall is the sum of one month's data

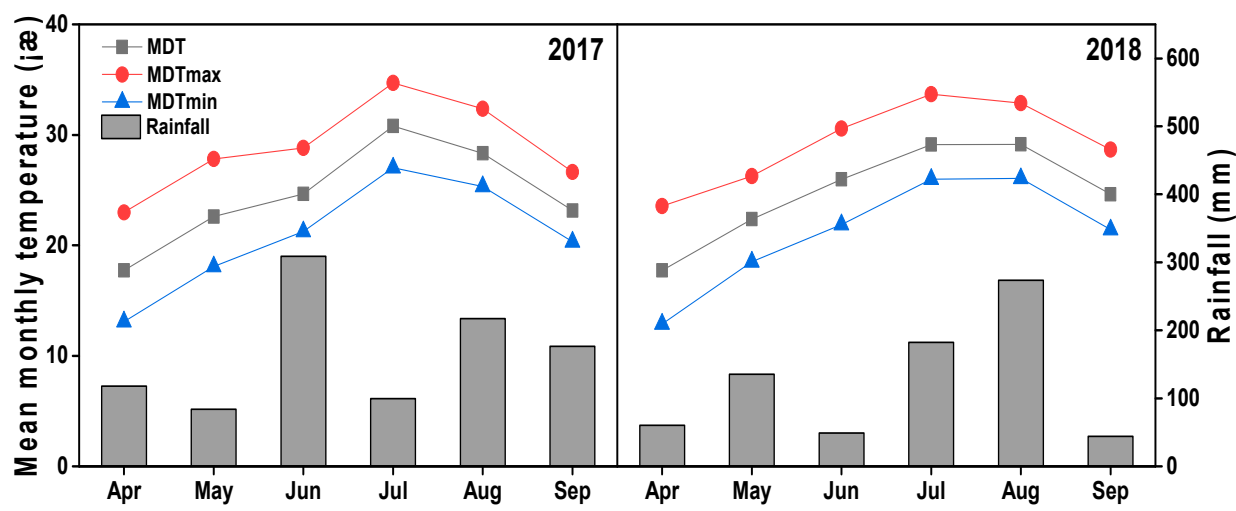

Figure 1. Mean monthly air temperature and rainfall during 2017 and 2018.

\subsection{Experimental Design, Treatments, and Crop Management}

The experiment was designed in a split-plot arrangement with two cotton cultivars (Lu-54: low-P-sensitive and Yuzaomian-9110: low-P-tolerant) [25] in main plots and three P rates (P0: 0, P1: 100, and P2: $200 \mathrm{~kg} \mathrm{P}_{2} \mathrm{O}_{5} \mathrm{ha}^{-1}$ ) in subplots with three replications. Cotton seeds were sown in the middle of April which attained a three true leaf stage at 30 to 35 days. These seedlings were transplanted to the field on May 24, 2017 and 2018. Fertilizer, such as N and K, were applied at a rate of $225 \mathrm{~kg} \mathrm{ha}^{-1}$ of each to every experimental plot. All of the $\mathrm{K}$ was applied at pre-planting while $\mathrm{N}$ was applied in four different splits as basal dose $(20 \%)$, start of flowering $(25 \%)$, bloom stage $(40 \%)$, and end of flowering (15\%), according to the stages described by Baker et al. [26]. Other field and plant management practices were adopted according to the local cotton production practices.

\subsection{Soil and Plant Sampling}

Before seedlings transplanting, soil samples $(0-20$ and $20-40 \mathrm{~cm})$ were collected at three different locations from the field to make a composite sample from each plot. These sample were sealed and kept in an ice box immediately after collection. In the laboratory, the sample was divided into two equal parts. One portion was kept at $-20^{\circ} \mathrm{C}$ in a freezer and the other portion was kept outside in order to dry. The dried sample was meshed to make fine powder which was used for further analysis.

The plant samples were collected at five different times, i.e., squaring "SQ" ( 39 days after transplanting), first bloom "FB" (52 DAT), peak bloom "PB" (69 DAT), boll setting "BS" (83 DAT), and boll opening "BO" (99 DAT). Three plants from each plot were randomly collected and RO (bolls) were separated. The collected material was oven dried at $70{ }^{\circ} \mathrm{C}$ and dry matter was calculated on the base of per unit land area.

\subsection{Nutrients and Biomass Accumulation}

Total N, $\mathrm{P}$, and $\mathrm{K}$ were determined by the $\mathrm{H}_{2} \mathrm{SO}_{4}-\mathrm{H}_{2} \mathrm{O}_{2}$ extraction method. The samples were weighed, put in a glass tube, and heated at $350{ }^{\circ} \mathrm{C}$. $\mathrm{H}_{2} \mathrm{SO}_{4}$ was added followed by $\mathrm{H}_{2} \mathrm{O}_{2}$ in addition with pure water. Lastly, the solution was filtered, and filtrate was stored for further analysis.

Reproductive organ biomass was determined through destructive sampling by randomly selecting three cotton plants from each replication of treatments. Reproductive organs were separated from the plants and divided into three different parts (seed, bur, and lint). These parts were oven-dried first at $105{ }^{\circ} \mathrm{C}$ for $30 \mathrm{~min}$ and then at $80^{\circ} \mathrm{C}$ until constant dry weight and expressed as $\mathrm{kg} \mathrm{ha}^{-1}$. The process of $\mathrm{N}, \mathrm{P}, \mathrm{K}$, and biomass accumulation was described and calculated by the following logistics formulas [27].

$$
Y=\frac{K}{1+a e^{b t}}
$$


where " $t$ " denotes to the DAT, $Y(\mathrm{~g})$ represents the accumulation of $K$ at $t, K(\mathrm{~g})$ signifies the higher accumulation biomass value for $K$, while " $a$ " and " $b$ " are constants.

From Equation (1), the following formulas can be derived;

$$
\begin{gathered}
t_{1}=\frac{1}{b} \ln (2+\sqrt{ } 3) \\
t_{2}=\frac{1}{b} \ln (2-\sqrt{ } 3) \\
t_{m}=-\ln \frac{a}{b}
\end{gathered}
$$

The starting point denotes $\left(t_{1}\right)$, ending point $\left(t_{2}\right)$, and $\left(T=t_{2}-t_{1}\right)$ represents the difference of starting and ending time.

$$
\begin{gathered}
V_{M}=\frac{-b k}{4} \\
V_{T}=\frac{\Delta Y}{\Delta t}=\left(Y_{2}-Y_{1}\right)\left(t_{2}-t_{1}\right)
\end{gathered}
$$

The fast accumulation period (FAP) can be explained as the period accumulating N, P, K, and biomass that starts and ends with an average speed of $\left(V_{\mathrm{T}}\right)$, average maximum speed $\left(V_{\mathrm{M}}\right)$ during FAP. Whereas $Y_{1}$ and $Y_{2}$ represent weight (N, $\mathrm{P}, \mathrm{K}$, and biomass) at $t_{1}$ and $t_{2}$, respectively, and can be calculated as above.

In each subplot, two rows were selected for seed cotton yield. Opened bolls were hand-picked from the two rows, seeds were removed to calculate seed yield, and expressed as $\mathrm{kg} \mathrm{ha}^{-1}$.

\subsection{Data Analysis}

Data were processed by using Microsoft Excel 2013. Statistical analysis was carried out by Statistix 8.1 (Analytical Software, Tallahassee, FL, USA). Mean difference between the treatments were separated by the least significant difference (LSD) test at the probability level of 0.05 . Origin 9.1, Sigma plot 12.0 (Systat Software Inc., San Jose, CA, USA), and R 3.6.1 were employed to draw figures.

\section{Results}

\subsection{Seed Cotton Yield}

Phosphorus application expressively affected the seed cotton yield with a different trend in 2017 and 2018 (Figure 2). Seed cotton yield in 2017 was significantly higher than in 2018. The control treatment showed the lowest seed cotton yield compared with the other P application (Figure 2). Comparison of treatments showed that P1 and P2 increased the seed cotton yield by $23.9 \%-34.5 \%$ and $30.8 \%-52.3 \%$ for Lu-54 and 16.6\%-25.6\% and 20.6\%-38.5\% for Yuzaomian-9110 during 2017 and 2018 , respectively.

\subsection{Nitrogen Accumulation in Reproductive Organ}

Nitrogen accumulation in RO of cotton plant represents a sigmoid curve with DAT. The early growth stage showed a quick average speed of accumulation of $\mathrm{N}$ and then gradually decreased in the later stage (Figure 3). The P application had a drastic effect on the accumulation of $\mathrm{N}$ content arrangement in the $\mathrm{RO}$ of cotton throughout the growing period after transplanting. Compared with the control, the final amount of $\mathrm{N}$ accumulation in $\mathrm{P}$ treatments $\left(100\right.$ and $\left.200 \mathrm{~kg} \mathrm{P}_{2} \mathrm{O}_{5} \mathrm{ha}^{-1}\right)$ increased by $24.0 \%-46.9 \%$ and $23.3 \%-47.1 \%$ in Lu- 54 and $36.9 \%-67.9 \%$ and $21.8 \%-58.2 \%$ in Yuzaomian- 9110 during 2017 and 2018, respectively. The RO N content was drastically increased with the increasing DAT and was highest at 83 DAT and continued to present the same accumulation at 99 DAT. During 2017, cotton plant accumulated comparatively more N in the RO than 2018. The difference of weather between the two years might be a big reason for change in N accumulation. Similarly, P2 showed 
higher $\mathrm{N}$ accumulated in the RO as compared with the control during 2017 and 2018, respectively (Figure 3).

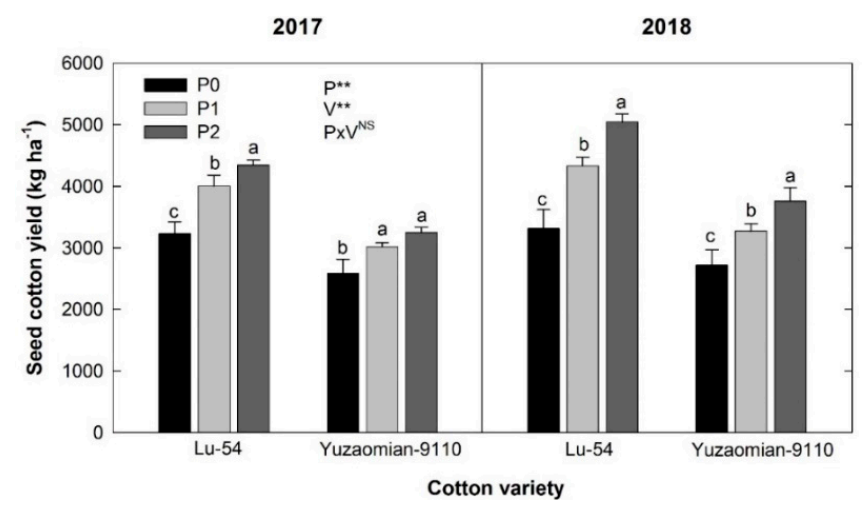

Figure 2. Seed cotton yield $\left(\mathrm{kg} \mathrm{ha}^{-1}\right)$ as affected by phosphorus (P) levels during 2017 and 2018 in Lu-54 (low P sensitive) and Yuzaomian-9110 (low P tolerant). P0, P1, and P2 indicate P levels of 0, 100, and $200 \mathrm{~kg} \mathrm{P}_{2} \mathrm{O}_{5} \mathrm{ha}^{-1}$, respectively. Whereas $\mathrm{P}, \mathrm{V}$, and $\mathrm{P} \times \mathrm{V}$ represent phosphorus, cultivar, and their interaction, respectively. While ${ }^{* *}$ and NS show highly significant and non-significant, respectively. Vertical bars on the columns indicate standard errors of the mean $(n=3)$. The bars showing different letters are statistically significant at $p \leq 0.05$.
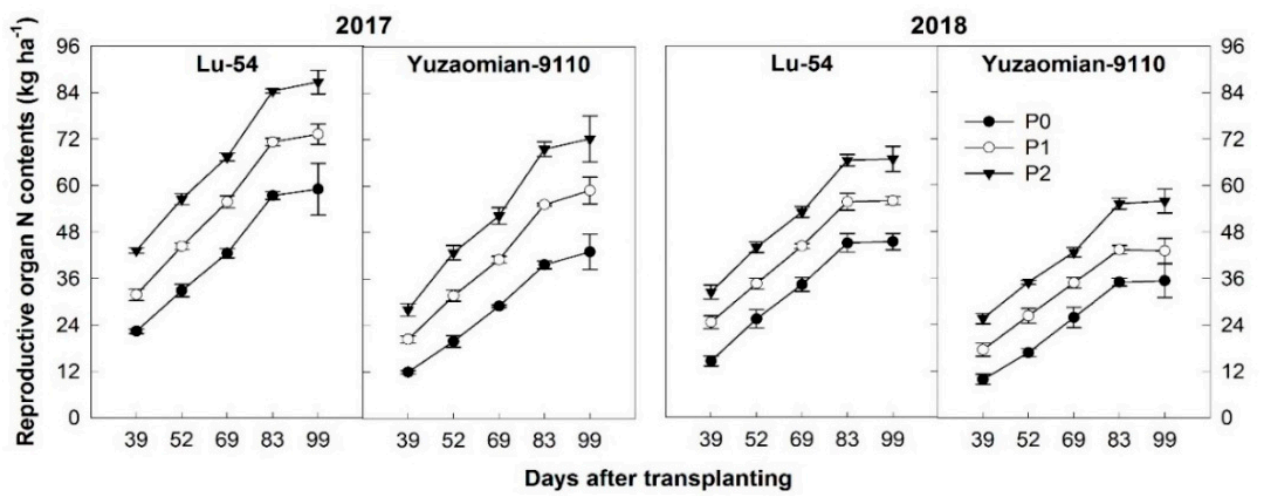

Figure 3. The accumulation of total $\mathrm{N}$ contents $\left(\mathrm{kg} \mathrm{ha}^{-1}\right)$ in reproductive organ of cotton plant for Lu-54 and Yuzaomian-9110 in 2017 and 2018. The treatments P0, P1, and P2 represent the P levels, i.e., 0,100 , and $200 \mathrm{~kg} \mathrm{P}_{2} \mathrm{O}_{5} \mathrm{ha}^{-1}$. The data are the means of three replications \pm standard error.

\subsection{Simulation of $N$ Accumulation}

Calculating overall data and fitting these into Formula (1) resulted in overall determination coefficients being high $\left(R^{2} \geq 0.9383^{* *}, p<0.01\right.$, Table 2$)$, concluding that logistic function was the most suitable for accumulation of $\mathrm{N}$. The $\mathrm{K}$ in the P application treatments (P1 and P2) over control was increased by $14.0 \%-69.8 \%$ and $27.2 \%-66.8 \%$ for Lu- 54 and $40.2 \%-39.0 \%$ and $20.3 \%-65.4 \%$ for Yuzaomian-9110 during 2017 and 2018, respectively. Calculations based on Formulas (2)-(6) indicated that the $\mathrm{T}$ was increased consistently by increasing $\mathrm{P}$ application in both cultivars during 2017 and 2018. The $V_{T}$ and $V_{M}$ calculated in the $P$ application treatments were higher compared with the control treatment for both cultivars in both growing seasons. Based on the calculations from Formulas (2)-(6), it was indicated that initiation and termination day of 77 and 57, fast accumulation period of $\mathrm{N}$ accumulation in the RO was 26 and 22 and 104 and 79 DAT for Lu-54 and 65 and 55 d FAP for $\mathrm{N}$ accumulation was 35 and 27 and 101 and 82 DAT for Yuzaomian-9110, during 2017 and 2018, respectively. The fluctuating trend was observed across two years in different treatments with an average maximum speed $\left(\mathrm{V}_{\mathrm{M}}\right)$ recorded higher than the average speed $\left(\mathrm{V}_{\mathrm{T}}\right)$. The P0 began FAP last at 39 DAT and terminated at 119 DAT, stayed for $80 \mathrm{~d}$ with the maximum average speed of $0.8 \mathrm{~kg} \mathrm{ha}^{-1}$ 
$\mathrm{d}^{-1}$, which was the same as the average speed of P1 with different starting and termination DAT in Lu-54 during 2017; however, the P2 began the fast accumulation period the earliest at 15 DAT and terminated at $84 \mathrm{DAT}$, and stayed for $69 \mathrm{~d}$ with the $\mathrm{V}_{\mathrm{M}}$ of $0.6 \mathrm{~kg} \mathrm{ha}^{-1} \mathrm{~d}^{-1}$ during 2018 , which was recorded lower than in 2017. The same trend was observed for Yuzaomian-9110 with a lower average speed than Lu-54 during 2017 and 2018.

\subsection{Phosphorus Accumulation in Reproductive Organ}

Accumulation of P in RO of cotton cultivars showed a sigmoid curve with DAT (Figure 4). The average speed of $\mathrm{P}$ accumulation in $\mathrm{RO}$ increased in the early growth stages and then slowed a little at the late period. The P supply had a significant effect on the $\mathrm{P}$ accumulation pattern throughout the growth period after transplanting of cotton. Compared with the control, the amount of accumulated $\mathrm{P}$ in P application treatment (P1 and P2) increased by $43.5 \%-91.0 \%$ and $30.4 \%-65.3 \%$ for Lu-54 and $50.3 \%-108.7 \%$ and $52.9 \%-100.6 \%$ for Yuzaomian-9110 during 2017 and 2018, respectively. The P content in the RO of cotton was drastically increased with the increase of DAT and recorded the highest at 99 DAT in 2017; however, in 2018, it was recorded the highest at 83 DAT and continued with same the trend at 99 DAT. The P accumulated in the RO were recorded higher in 2017 compared with 2018. The P2 resulted in higher P in RO of cotton as compared to P0 in both cropping seasons (Figure 4).

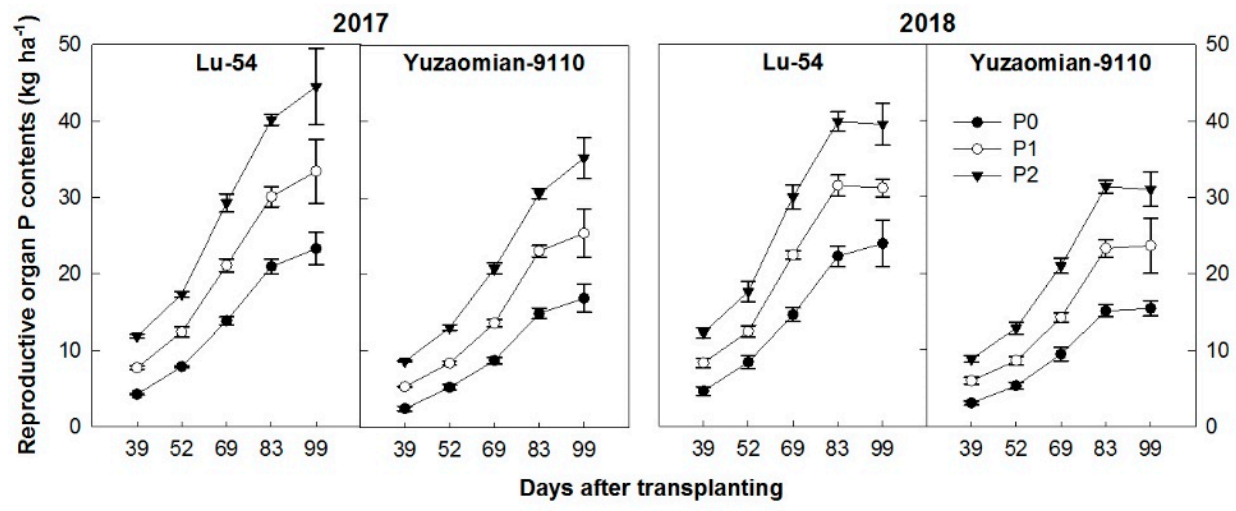

Figure 4. The accumulation of total $\mathrm{P}$ contents $\left(\mathrm{kg} \mathrm{ha}^{-1}\right)$ in reproductive organ of cotton plant for Lu-54 and Yuzaomian-9110 in 2017 and 2018. The treatments P0, P1, and P2 represent the P levels, i.e., 0, 100 and $200 \mathrm{P}_{2} \mathrm{O}_{5} \mathrm{~kg} \mathrm{ha}^{-1}$. The data are the means of three replications \pm standard error.

\subsection{Simulation of P Accumulation}

The determination coefficient derived from the data fitting into Formula (1) indicated that it was low $\left(R^{2} \geq 0.9495^{* *}, p<0.05\right.$, Table 3) and high $\left(R^{2} \geq 0.9956^{* *}, p<0.01\right.$, Table 3), and confirmed the best indication of logistic function to define $\mathrm{P}$ accumulation in $\mathrm{RO}$ of cotton. The $\mathrm{K}$ in the $\mathrm{P}$ application-supply treatments was increased by $70.3 \%-202.7 \%$ and $14.2 \%-56.9 \%$ for Lu- 54 and $181.1 \%-145.7 \%$ and $185.7 \%-136.1 \%$ for Yuzaomian-9110 in comparison with the control during 2017 and 2018, respectively. The calculation regarding T from Formulas (2)-(6) grounded in Table 3 confirmed the increased $T$ with increasing P levels in 2017 and 2018 for both cultivars. The $V_{T}$ and $V_{M}$ were recorded as higher in the $\mathrm{P}$ application treatments compared with the control for both the cultivars (Table 3). On an average basis across all the treatments, the accumulation of $P$ which initiated and terminated the fast accumulation period of $56 \mathrm{~d}$ were at 48 DAT and 104 DAT for Lu-54, while at 61 d, they were at 58 DAT and 119 DAT for Yuzaomian-9110 during 2017, respectively. During 2018, P accumulation starting and finishing the $46 \mathrm{~d}$ were 40 DAT and 86 DAT for Lu-54, while at $54 \mathrm{~d}$, they were at 48 DAT and 103 DAT for Yuzaomian-9110 during 2017 and 2018, respectively. The increasing $\mathrm{P}$ application increased the $\mathrm{V}_{\mathrm{M}}$ compared to $\mathrm{V}_{\mathrm{T}}$ across the two years. The increased $\mathrm{P}$ application linearly increased the $V_{M}$ and $V_{T}$ during 2017 and 2018, respectively (Table 3). 
Table 2. Dynamic models and the maximum accumulation rate of $\mathrm{N}\left(\mathrm{V}_{\mathrm{M}}\right)$, average speed of $\mathrm{N}$ accumulation $\left(\mathrm{V}_{\mathrm{T}}\right)$, start time of the $\mathrm{N}$ rapid-accumulation period ( $\mathrm{t}_{1}$ ), termination time of the $\mathrm{N}$ rapid-accumulation period $\left(\mathrm{t}_{2}\right)$, duration of the $\mathrm{N}$ rapid-accumulation period ( $\mathrm{T}$ ), and occurrence time of maximum accumulation rate of $\mathrm{N}$ $\left(t_{m}\right)$ in reproductive organ of cotton plants for Lu-54 and Yuzaomian-9110 in 2017 and 2018.

\begin{tabular}{|c|c|c|c|c|c|c|c|c|c|c|}
\hline \multirow{2}{*}{ Year } & \multirow{2}{*}{ Variety } & \multirow{2}{*}{$\begin{array}{l}\text { P Levels } \\
\left(\mathrm{kg} \mathrm{ha}^{-1}\right)\end{array}$} & \multirow{2}{*}{ Regression Equation } & \multirow{2}{*}{$R^{2}$} & \multicolumn{2}{|c|}{ Fast Accumulation Period } & \multirow{2}{*}{$T(d)$} & \multirow{2}{*}{$\begin{array}{c}\mathrm{V}_{\mathrm{T}} \\
\left(\mathrm{kgha}^{-1} \mathrm{~d}^{-1}\right)\end{array}$} & \multicolumn{2}{|c|}{ Fastest Accumulation Point } \\
\hline & & & & & $t_{1}(d)$ & $t_{2}(d)$ & & & $V_{m}\left(k_{g h a^{-1}} d^{-1}\right)$ & $t_{m}(d)$ \\
\hline \multirow{8}{*}{2017} & \multirow{4}{*}{ Lu-54 } & P0 & $\mathrm{W}=76.9 /\left(1+13.41 \mathrm{e}^{-0.0327 \mathrm{t}}\right)$ & $0.9856^{* *}$ & 39.1 & 119.5 & 80.4 & 0.8 & 0.87 & 79.3 \\
\hline & & P1 & $\mathrm{W}=87.72 /\left(1+9.56 \mathrm{e}^{-0.0435 t}\right)$ & $0.9685^{* *}$ & 21.6 & 82.2 & 60.6 & 0.8 & 0.95 & 51.9 \\
\hline & & P2 & $\mathrm{W}=130.65 /\left(1+6.28 \mathrm{e}^{-0.0290 t}\right)$ & $0.9766^{* *}$ & 17.9 & 108.7 & 90.8 & 0.9 & 0.95 & 63.3 \\
\hline & & Mean & & & 26.2 & 103.5 & 77.3 & 0.8 & 0.92 & 64.8 \\
\hline & \multirow{4}{*}{ Yuzaomian-9110 } & P0 & $\mathrm{W}=65.54 /\left(1+23.43 \mathrm{e}^{-0.0425 t}\right)$ & $0.9946 * *$ & 43.3 & 105.3 & 62.0 & 0.6 & 0.70 & 74.3 \\
\hline & & P1 & $\mathrm{W}=91.91 /\left(1+14.97 \mathrm{e}^{-0.0374 t}\right)$ & $0.9806^{* *}$ & 37.2 & 107.7 & 70.5 & 0.8 & 0.86 & 72.5 \\
\hline & & P2 & $\mathrm{W}=91.11 /\left(1+10.86 \mathrm{e}^{-0.0414 t}\right)$ & $0.9555^{* *}$ & 25.8 & 89.4 & 63.6 & 0.8 & 0.94 & 57.6 \\
\hline & & Mean & & & 35.4 & 100.8 & 65.4 & 0.7 & 0.83 & 68.1 \\
\hline \multirow{8}{*}{2018} & \multirow{4}{*}{ Lu-54 } & P0 & $\mathrm{W}=48.89 /\left(1+25.35 \mathrm{e}^{-0.0614 t}\right)$ & $0.9787^{* *}$ & 31.2 & 74.2 & 42.9 & 0.5 & 0.75 & 52.7 \\
\hline & & P1 & $\mathrm{W}=62.17 /\left(1+8.54 \mathrm{e}^{-0.0446 \mathrm{t}}\right)$ & $0.9720 * *$ & 18.6 & 77.6 & 59.1 & 0.5 & 0.69 & 48.1 \\
\hline & & P2 & $\mathrm{W}=81.53 /\left(1+6.55 \mathrm{e}^{-0.0381 \mathrm{t}}\right)$ & $0.9387^{* *}$ & 14.8 & 83.9 & 69.1 & 0.6 & 0.78 & 49.3 \\
\hline & & Mean & & & 21.5 & 78.6 & 57.0 & 0.6 & 0.74 & 50.0 \\
\hline & \multirow{4}{*}{ Yuzaomian-9110 } & P0 & $\mathrm{W}=42.35 /\left(1+37.06 \mathrm{e}^{-0.0616 \mathrm{t}}\right)$ & $0.9901^{* *}$ & 37.2 & 80.0 & 42.7 & 0.5 & 0.65 & 58.6 \\
\hline & & $\mathrm{P} 1$ & $\mathrm{~W}=50.94 /\left(1+14.06 \mathrm{e}^{-0.0513 t}\right)$ & $0.9681^{* *}$ & 25.9 & 77.2 & 51.4 & 0.5 & 0.65 & 51.5 \\
\hline & & P2 & $\mathrm{W}=70.04 /\left(1+6.83 \mathrm{e}^{-0.0366 \mathrm{t}}\right)$ & $0.9383 * *$ & 16.5 & 88.4 & 71.9 & 0.5 & 0.64 & 52.5 \\
\hline & & Mean & & & 26.5 & 81.9 & 55.3 & 0.5 & 0.65 & 54.2 \\
\hline
\end{tabular}

The treatments P0, P1, and P2 represent the P levels, i.e., 0, 100, and $200 \mathrm{~kg} \mathrm{P}_{2} \mathrm{O}_{5}$ ha $^{-1}$. ${ }^{* *}$ represents highly significant. 
Table 3. Dynamic models and the maximum accumulation rate of $P\left(V_{M}\right)$, average speed of $P$ accumulation $\left(V_{T}\right)$, start time of the $P$ rapid-accumulation period ( $\left.t_{1}\right)$, termination time of the $\mathrm{P}$ rapid-accumulation period $\left(\mathrm{t}_{2}\right)$, duration of the $\mathrm{P}$ rapid-accumulation period $(\mathrm{T})$, and occurrence time of maximum accumulation rate of $\mathrm{P}$ $\left(t_{m}\right)$ in reproductive organ of cotton plants for Lu-54 and Yuzaomian-9110 in 2017 and 2018.

\begin{tabular}{|c|c|c|c|c|c|c|c|c|c|c|}
\hline \multirow{2}{*}{ Year } & \multirow{2}{*}{ Variety } & \multirow{2}{*}{$\begin{array}{l}\text { P Levels } \\
\left(\mathrm{kg} \mathrm{ha}^{-1}\right)\end{array}$} & \multirow{2}{*}{ Regression Equation } & \multirow{2}{*}{$\mathrm{R}^{2}$} & \multicolumn{2}{|c|}{ Fast Accumulation Period } & \multirow{2}{*}{$\mathrm{T}(\mathrm{d})$} & \multirow{2}{*}{$\frac{V_{T}}{\left(\mathrm{kgha}^{-1} \mathrm{~d}^{-1}\right)}$} & \multicolumn{2}{|c|}{ Fastest Accumulation Point } \\
\hline & & & & & $t_{1}(d)$ & $t_{2}(d)$ & & & $V_{m}\left(k_{g ~ h a}{ }^{-1} d^{-1}\right)$ & $t_{m}(d)$ \\
\hline \multirow{8}{*}{2017} & \multirow{4}{*}{ Lu-54 } & P0 & $\mathrm{W}=27.92 /\left(1+56.75 \mathrm{e}^{-0.0596 \mathrm{t}}\right)$ & $0.9955^{* *}$ & 45.7 & 89.8 & 44.2 & 0.3 & 0.42 & 67.7 \\
\hline & & P1 & $\mathrm{W}=47.57 /\left(1+33.64 \mathrm{e}^{-0.0481 \mathrm{t}}\right)$ & $0.9956 * *$ & 45.8 & 100.7 & 54.9 & 0.5 & 0.57 & 73.3 \\
\hline & & P2 & $\mathrm{W}=84.52 /\left(1+28.50 \mathrm{e}^{-0.0391 \mathrm{t}}\right)$ & $0.9937^{* *}$ & 52.2 & 119.8 & 67.6 & 0.7 & 0.82 & 86.0 \\
\hline & & Mean & & & 47.9 & 103.5 & 55.6 & 0.5 & 0.60 & 75.7 \\
\hline & \multirow{4}{*}{ Yuzaomian-9110 } & P0 & $\mathrm{W}=24.70 /\left(1+68.20 \mathrm{e}^{-0.0538 \mathrm{t}}\right)$ & $0.9636^{* *}$ & 54.0 & 102.9 & 48.9 & 0.3 & 0.33 & 78.4 \\
\hline & & P1 & $\mathrm{W}=69.44 /\left(1+18.79 \mathrm{e}^{-0.0383 \mathrm{t}}\right)$ & $0.9798 * *$ & 42.2 & 110.9 & 68.7 & 0.4 & 0.67 & 76.5 \\
\hline & & P2 & $\mathrm{W}=60.69 /\left(1+28.89 \mathrm{e}^{-0.0401 \mathrm{t}}\right)$ & $0.9933^{* *}$ & 51.0 & 116.7 & 65.7 & 0.5 & 0.61 & 83.9 \\
\hline & & Mean & & & 58.2 & 119.3 & 61.1 & 0.4 & 0.54 & 88.8 \\
\hline \multirow{8}{*}{2018} & \multirow{4}{*}{ Lu-54 } & P0 & $\mathrm{W}=30.99 /\left(1+53.32 \mathrm{e}^{-0.0569 t}\right)$ & $0.9846^{* *}$ & 46.7 & 92.9 & 46.2 & 0.4 & 0.44 & 69.8 \\
\hline & & P1 & $\mathrm{W}=35.41 /\left(1+40.24 \mathrm{e}^{-0.0616 \mathrm{t}}\right)$ & $0.9687^{* *}$ & 38.6 & 81.3 & 42.7 & 0.4 & 0.55 & 60.0 \\
\hline & & P2 & $\mathrm{W}=48.60 /\left(1+27.26 \mathrm{e}^{-0.0555 \mathrm{t}}\right)$ & $0.9737^{* *}$ & 35.8 & 83.2 & 47.4 & 0.5 & 0.68 & 59.5 \\
\hline & & Mean & & & 40.4 & 85.8 & 45.5 & 0.4 & 0.55 & 63.1 \\
\hline & \multirow{4}{*}{ Yuzaomian-9110 } & P0 & $\mathrm{W}=18.44 /\left(1+59.68 \mathrm{e}^{-0.0627 t}\right)$ & $0.9716^{* *}$ & 44.2 & 86.2 & 42.0 & 0.2 & 0.29 & 65.2 \\
\hline & & $\mathrm{P} 1$ & $W=52.69 /\left(1+28.02 \mathrm{e}^{-0.0388 \mathrm{t}}\right)$ & $0.9495^{* *}$ & 51.9 & 119.7 & 67.8 & 0.4 & 0.51 & 85.8 \\
\hline & & P2 & $\mathrm{W}=43.54 /\left(1+28.22 \mathrm{e}^{-0.0494 \mathrm{t}}\right)$ & $0.9606^{* *}$ & 41.0 & 94.3 & 53.4 & 0.5 & 0.54 & 67.7 \\
\hline & & Mean & & & 48.1 & 102.5 & 54.4 & 0.4 & 0.45 & 75.3 \\
\hline
\end{tabular}

The treatments $\mathrm{P} 0, \mathrm{P} 1$, and $\mathrm{P} 2$ represent the $\mathrm{P}$ levels, i.e., 0,100 , and $200 \mathrm{~kg} \mathrm{P}_{2} \mathrm{O}_{5}$ ha $^{-1}$. ${ }^{* *}$ represents highly significant. 


\subsection{Potassium Accumulation in Reproductive Organ}

Cotton plant potassium uptake increased with the advancement in growth stages following a normal exponential growth curve with DAT (Figure 5). A momentous effect of phosphorus application on $\mathrm{K}$ status of plant at different growth stages after transplanting of cotton seedlings was observed. Compared with the control treatment, $\mathrm{P} 1$ and $\mathrm{P} 2$ increased $\mathrm{K}$ in $\mathrm{RO}$ by $27.0 \%-46.0 \%$ and $23.3 \%-47.1 \%$ in Lu-54 and $21.0 \%-40.9 \%$ and $21.8 \%-58.2 \%$ in Yuzaomian-9110 during 2017 and 2018, respectively. Along with the plant age, $\mathrm{P}$ application increased the accumulation of $\mathrm{K}$ until $83 \mathrm{DAT}$ and then remained constant until 99 DAT.
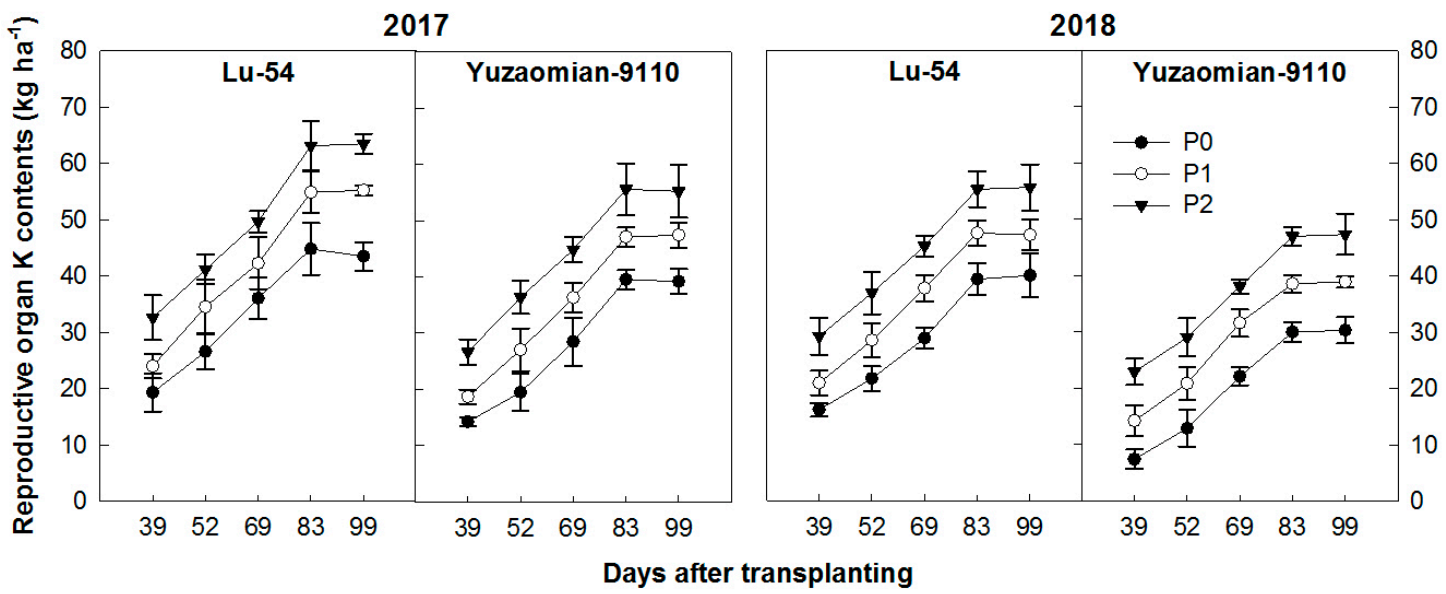

Figure 5. The accumulation of total $\mathrm{K}$ contents $\left(\mathrm{kg} \mathrm{ha}^{-1}\right)$ in reproductive organ of cotton plant for Lu-54 and Yuzaomian-9110 in 2017 and 2018. The treatments P0, P1, and P2 represent the P levels, i.e., 0, 100, and $200 \mathrm{~kg} \mathrm{P}_{2} \mathrm{O}_{5} \mathrm{ha}^{-1}$. The data are the means of three replications \pm standard error.

\subsection{Simulation of $K$}

The experimental data were used in a Formula (1) to determine the simulation of $\mathrm{K}$ accumulation with cotton growth stages. The accumulation of $K$ as a normal sigmoid curve were the best fitted in the logistic function since all the determination coefficients were high $\left(R^{2} \geq 0.9408 * *, p<0.01\right.$, Table 4). The $\mathrm{K}$ in the P1 and P2 treatments were increased by $26.5 \%-63.5 \%$ and $27.2 \%-66.8 \%$ in Lu- 54 and $20.7 \%-43.1 \%$ and $20.3 \%-65.4 \%$ during 2017 and 2018 respectively, over the control. Data obtained from Formulas (2)-(6), exhibited that the starting and ending day of $\mathrm{K}$ uptake for cultivars and $\mathrm{P}$ application showed that $\mathrm{T}$ was higher with the application of $\mathrm{P}$ in 2017 while it was inconsistent across 2018 in Lu-54 and Yuzaomian-9110, respectively (Table 4). The $\mathrm{V}_{\mathrm{T}}$ and $\mathrm{V}_{\mathrm{M}}$ were relatively higher in $P$ application over the control for both cultivars. Data obtained from Formulas (2)-(6) revealed that initiation and termination day of $58 \mathrm{~d}$ FAP for accumulation of $\mathrm{K}$ was 17 and 75 DAT averaged across the treatments for Lu-54, while $60 \mathrm{~d}$ was 15 DAT and 75 DAT averaged for Yuzaomian-9110 in 2017, respectively. In 2018, 66 d FAP of K was 19 and 85 DAT for Lu-54 while $48 \mathrm{~d}$ was 29 DAT and 77 DAT for $48 \mathrm{~d}$ was $29 \mathrm{DAT}$ and 77 DAT for Yuzaomian-9110, respectively. The $\mathrm{V}_{\mathrm{M}}$ was recorded as higher than $\mathrm{V}_{\mathrm{T}}$ with different inclination between the treatments during two cropping seasons. The longer period (80-73 d) was observed in Lu-54, while Yuzaomian-9110 showed a relatively shorter period (60-69 d) at P2 treatment compared with the P0 and P1 during 2017 and 2018, respectively. 
Table 4. Dynamic models and the maximum accumulation rate of $\mathrm{K}\left(\mathrm{V}_{\mathrm{M}}\right)$, average speed of $\mathrm{K}$ accumulation $\left(\mathrm{V}_{\mathrm{T}}\right)$, start time of the $\mathrm{K}$ rapid-accumulation period ( $\mathrm{t}_{1}$ ), termination time of the $\mathrm{K}$ rapid-accumulation period $\left(\mathrm{t}_{2}\right)$, duration of the $\mathrm{K}$ rapid-accumulation period $(\mathrm{T})$, and occurrence time of maximum accumulation rate of $\mathrm{K}$ $\left(t_{m}\right)$ in reproductive organ of cotton plants for Lu-54 and Yuzaomian-9110 in 2017 and 2018.

\begin{tabular}{|c|c|c|c|c|c|c|c|c|c|c|}
\hline \multirow{2}{*}{ Year } & \multirow{2}{*}{ Variety } & \multirow{2}{*}{$\begin{array}{l}\text { P Levels } \\
\left(\mathrm{kg} \mathrm{ha}^{-1}\right)\end{array}$} & \multirow{2}{*}{ Regression Equation } & \multirow{2}{*}{$R^{2}$} & \multicolumn{2}{|c|}{ Fast Accumulation Period } & \multirow{2}{*}{$\mathrm{T}(\mathrm{d})$} & \multirow{2}{*}{$\frac{V_{T}}{\left(\mathrm{kgha}^{-1} \mathrm{~d}^{-1}\right)}$} & \multicolumn{2}{|c|}{ Fastest Accumulation Point } \\
\hline & & & & & $t_{1}(d)$ & $t_{2}(d)$ & & & $V_{m}\left(k_{g ~ h a}{ }^{-1} d^{-1}\right)$ & $t_{m}(d)$ \\
\hline \multirow{8}{*}{2017} & \multirow{4}{*}{ Lu-54 } & P0 & $\mathrm{W}=46.13 /\left(1+13.92 \mathrm{e}^{-0.0577 t}\right)$ & $0.9665^{* *}$ & 22.8 & 68.4 & 45.6 & 0.42 & 0.67 & 45.6 \\
\hline & & P1 & $W=58.34 /\left(1+12.09 \mathrm{e}^{-0.0546 t}\right)$ & $0.9865^{* *}$ & 21.5 & 69.8 & 48.2 & 0.52 & 0.80 & 45.6 \\
\hline & & P2 & $\mathrm{W}=75.43 /\left(1+4.75 \mathrm{e}^{-0.0329 \mathrm{t}}\right)$ & $0.9568^{* *}$ & 7.3 & 87.2 & 79.9 & 0.52 & 0.62 & 47.3 \\
\hline & & Mean & & & 17.2 & 75.1 & 57.9 & 0.49 & 0.69 & 46.2 \\
\hline & \multirow{4}{*}{ Yuzaomian-9110 } & P0 & $\mathrm{W}=43.21 /\left(1+21.62 \mathrm{e}^{-0.0602 \mathrm{t}}\right)$ & $0.9758 * *$ & 29.1 & 72.9 & 43.7 & 0.45 & 0.65 & 51.0 \\
\hline & & $\mathrm{P} 1$ & $\mathrm{~W}=52.13 /\left(1+16.21 \mathrm{e}^{-0.0561 \mathrm{t}}\right)$ & $0.9761 * *$ & 26.2 & 73.1 & 46.9 & 0.51 & 0.73 & 49.6 \\
\hline & & P2 & $\mathrm{W}=61.81 /\left(1+7.21 \mathrm{e}^{-0.0437 \mathrm{t}}\right)$ & $0.9698^{* *}$ & 15.0 & 75.2 & 60.2 & 0.49 & 0.68 & 45.1 \\
\hline & & Mean & & & 23.4 & 73.7 & 50.3 & 0.48 & 0.69 & 48.6 \\
\hline \multirow{8}{*}{2018} & \multirow{4}{*}{ Lu-54 } & P0 & $\mathrm{W}=53.17 /\left(1+9.58 \mathrm{e}^{-0.0364 \mathrm{t}}\right)$ & $0.9615^{* *}$ & 25.9 & 98.3 & 72.3 & 0.44 & 0.48 & 62.1 \\
\hline & & P1 & $\mathrm{W}=52.57 /\left(1+11.49 \mathrm{e}^{-0.0510 t}\right)$ & $0.9555^{* *}$ & 22.0 & 73.7 & 51.6 & 0.48 & 0.67 & 47.9 \\
\hline & & P2 & $\mathrm{W}=66.28 /\left(1+5.25 \mathrm{e}^{-0.0359 t}\right)$ & $0.9408^{* *}$ & 9.5 & 82.9 & 73.3 & 0.48 & 0.59 & 46.2 \\
\hline & & Mean & & & 19.2 & 84.9 & 65.8 & 0.46 & 0.58 & 52.0 \\
\hline & \multirow{4}{*}{ Yuzaomian-9110 } & P0 & $\mathrm{W}=33.54 /\left(1+55.41 \mathrm{e}^{-0.0692 \mathrm{t}}\right)$ & $0.9764^{* *}$ & 39.0 & 77.0 & 38.0 & 0.41 & 0.58 & 58.0 \\
\hline & & $\mathrm{P} 1$ & $\mathrm{~W}=40.41 /\left(1+34.96 \mathrm{e}^{-0.0724 t}\right)$ & $0.9702 * *$ & 30.9 & 67.3 & 36.4 & 0.44 & 0.73 & 49.1 \\
\hline & & P2 & $\mathrm{W}=59.06 /\left(1+7.37 \mathrm{e}^{-0.0385 \mathrm{t}}\right)$ & $0.9442 * *$ & 17.7 & 86.1 & 68.5 & 0.47 & 0.57 & 51.9 \\
\hline & & Mean & & & 29.2 & 76.8 & 47.6 & 0.44 & 0.63 & 53.0 \\
\hline
\end{tabular}

The treatments $\mathrm{P} 0, \mathrm{P} 1$, and $\mathrm{P} 2$ represent the $\mathrm{P}$ levels, i.e., 0,100 , and $200 \mathrm{~kg} \mathrm{P}_{2} \mathrm{O}_{5}$ ha $^{-1}$. ${ }^{* *}$ represents highly significant. 


\subsection{Biomass Accumulation in Reproductive Organ}

Cotton plant biomass accumulation followed a sigmoid curve with DAT (Figure 6). The average speed of biomass accumulation was the fastest at DAT and then recorded a similar accumulation with 83 DAT and 99 DAT in 2017, while in 2018, a higher biomass accumulation was recorded with the passage of the growth period. The significant effect by $\mathrm{P}$ application was observed on the accumulation of RO biomass throughout the growth period. The P1 and P2 improved RO biomass over the control, by $21.0 \%-52.1 \%$ and $28.5 \%-56.8 \%$ for Lu- 54 and $24.2 \%-56.8 \%$ and $38.5 \%-69.1 \%$ for Yuzaomian- 9110 during 2017 and 2018, respectively.

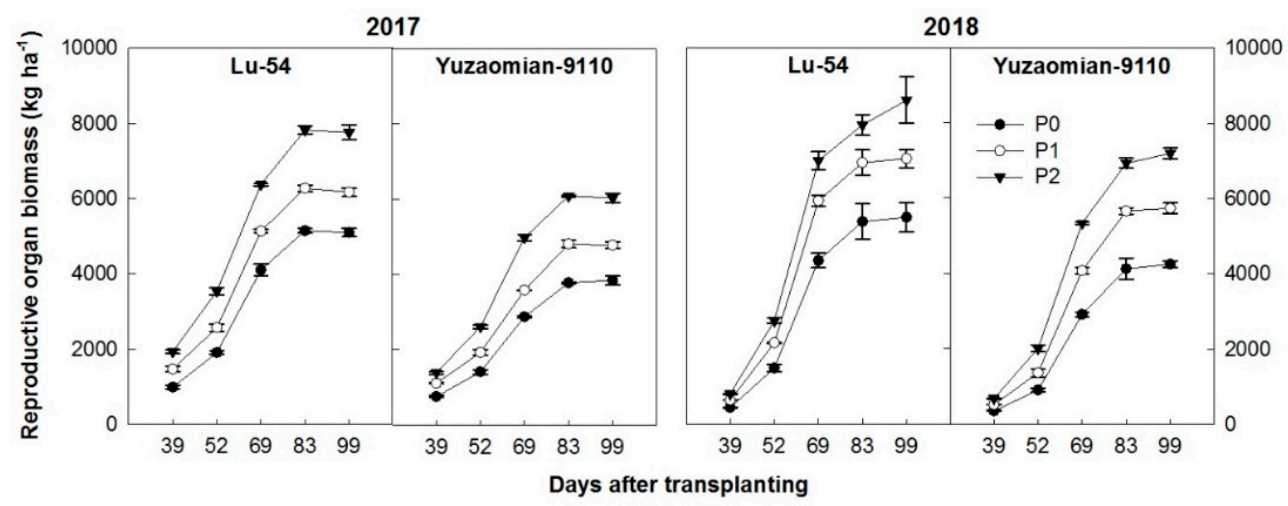

Figure 6. The accumulation of biomass in reproductive organ of cotton plant for Lu-54 and Yuzaomian-9110 in 2017 and 2018. The treatments P0, P1, and P2 represent the P levels, i.e., 0, 100 , and $200 \mathrm{~kg} \mathrm{P}_{2} \mathrm{O}_{5} \mathrm{ha}^{-1}$. The data are the means of three replications \pm standard error.

\subsection{Simulation of Biomass Accumulation}

The experimental data fitting into Formula (1) showed a normal logistic organism growth pattern and revealed that all the coefficients were high $\left(R^{2} \geq 0.9481^{* *}, p<0.01\right.$, Table 5$)$. The value of $\mathrm{K}$ in the P1 and P2 treatments over the control were improved by $11.3 \%-44.0 \%$ and $32.4 \%-53.3 \%$ for Lu- 54 and $20.3 \%-60.9 \%$ and $38.5 \%-67.5 \%$ for Yuzaomian-9110 during 2017 and 2018, respectively. Total biomass accumulation calculated by putting the data into Formulas (2)-(6) grounded in Table 5 indicated that the $T$ was unreliable across the years in both of the cultivars. The $V_{T}$ and $V_{M}$ were recorded as relatively higher in the $\mathrm{P}$ treatments compared with the control in both of the cultivars. Averaged across the treatments, the initiation and termination of the fast accumulation point of $34 \mathrm{~d}$ was 55 DAT and 88 DAT for Lu-54 and for 38 d was 55 DAT and 93 DAT for Yuzaomian-9110 in 2017, respectively. In 2018, RO biomass initiated and terminated the $28 \mathrm{~d}$ fast accumulation period at $65 \mathrm{DAT}$ and $93 \mathrm{DAT}$ for Lu-54, and the $27 \mathrm{~d}$ fast accumulation period of biomass at 63 DAT and 90 DAT for Yuzaomian-9110, respectively. Maximum and average speeds were apart from each other with higher maximum speed, followed by average speed averaged across the treatments in two cropping seasons. The P application increased the maximum and average speed by increasing the $\mathrm{P}$ level. The Lu-54 performance is better than Yuzaomian-9110 during 2017 and 2018, respectively (Table 5).

\subsection{Allocation of $N, P, K$, and Biomass in Cotton}

The total N, P, K, and biomass accumulation increased with the increase in P application in both cotton cultivars (Table 6). The accumulation of percentage of $\mathrm{N}$ in RO increased with the $\mathrm{P}$ treatments while cotton cultivars showed non-significant differences during 2017 and 2018. There were no understandable differences in the $\mathrm{P}$ and $\mathrm{K}$ accumulation of the $\mathrm{RO}$ recorded, neither with the application of P nor in cotton cultivars. Similarly, P treatment had no significant effect on the accumulation of biomass in the RO in 2017. However, in 2018, the cultivars showed a significant effect with a higher biomass accumulation in Lu-54 compared with Yuzaomian-9110 in P treatments over the control. 
Table 5. Dynamic models and the maximum accumulation rate of biomass $\left(\mathrm{V}_{\mathrm{M}}\right)$, average speed of biomass accumulation $\left(\mathrm{V}_{\mathrm{T}}\right)$, start time of the biomass rapid-accumulation period $\left(t_{1}\right)$, termination time of the biomass rapid-accumulation period $\left(t_{2}\right)$, duration of the biomass rapid-accumulation period $(T)$, and occurrence time of maximum accumulation rate of biomass $\left(t_{m}\right)$ in reproductive organ of cotton plants for Lu-54 and Yuzaomian-9110 in 2017 and 2018.

\begin{tabular}{|c|c|c|c|c|c|c|c|c|c|c|}
\hline \multirow{2}{*}{ Year } & \multirow{2}{*}{ Variety } & \multirow{2}{*}{$\begin{array}{l}\text { P Levels } \\
\left(\mathrm{kg} \mathrm{ha}^{-1}\right)\end{array}$} & \multirow{2}{*}{ Regression Equation } & \multirow{2}{*}{$R^{2}$} & \multicolumn{2}{|c|}{ Fast Accumulation Period } & \multirow{2}{*}{$T(d)$} & \multirow{2}{*}{$\frac{V_{T}}{\left(\mathrm{kgha}^{-1} \mathrm{~d}^{-1}\right)}$} & \multicolumn{2}{|c|}{ Fastest Accumulation Point } \\
\hline & & & & & $t_{1}(d)$ & $t_{2}(d)$ & & & $V_{m}\left(k g ~ h a ~^{-1} d^{-1}\right)$ & $t_{m}(d)$ \\
\hline \multirow{8}{*}{2017} & \multirow{4}{*}{ Lu-54 } & P0 & $\mathrm{W}=6029 /\left(1+267 \mathrm{e}^{-0.072 \mathrm{t}}\right)$ & $0.9616^{* *}$ & 59.4 & 96.0 & 36.6 & 77.3 & 108.41 & 77.7 \\
\hline & & P1 & $\mathrm{W}=6710 /\left(1+393 \mathrm{e}^{-0.085 t}\right)$ & $0.9481^{* *}$ & 54.7 & 85.6 & 30.9 & 86.6 & 142.95 & 70.1 \\
\hline & & P2 & $\mathrm{W}=8681 /\left(1+187 \mathrm{e}^{-0.075 t}\right)$ & 0.9796 ** & 52.3 & 87.4 & 35.2 & 105.9 & 162.60 & 69.8 \\
\hline & & Mean & & & 55.4 & 89.7 & 34.2 & 89.9 & 137.99 & 72.6 \\
\hline & \multirow{4}{*}{ Yuzaomian-9110 } & P0 & $\mathrm{W}=4427 /\left(1+234 \mathrm{e}^{-0.073 \mathrm{t}}\right)$ & $0.9879 * *$ & 57.0 & 93.2 & 36.2 & 56.2 & 80.46 & 75.1 \\
\hline & & P1 & $\mathrm{W}=5328 /\left(1+127 \mathrm{e}^{-0.067 \mathrm{t}}\right)$ & $0.9925 * *$ & 52.7 & 92.0 & 39.3 & 63.4 & 89.26 & 72.3 \\
\hline & & P2 & $\mathrm{W}=7125 /\left(1+176 \mathrm{e}^{0.071 \mathrm{t}}\right)$ & $0.9803^{* *}$ & 55.4 & 93.2 & 37.8 & 88.0 & 124.00 & 74.3 \\
\hline & & Mean & & & 55.0 & 92.8 & 37.8 & 69.2 & 97.91 & 73.9 \\
\hline \multirow{8}{*}{2018} & \multirow{4}{*}{ Lu-54 } & P0 & $\mathrm{W}=6173 /\left(1+2159 \mathrm{e}^{-0.098 \mathrm{t}}\right)$ & $0.9540^{* *}$ & 64.9 & 91.8 & 26.9 & 89.6 & 151.16 & 78.4 \\
\hline & & P1 & $\mathrm{W}=8174 /\left(1+1183 \mathrm{e}^{-0.088 \mathrm{t}}\right)$ & $0.9756^{* *}$ & 65.4 & 95.3 & 29.9 & 115.3 & 179.90 & 80.4 \\
\hline & & P2 & $W=9462 /\left(1+1323 e^{-0.092 t}\right)$ & $0.9729 * *$ & 63.6 & 92.1 & 28.5 & 134.5 & 218.39 & 77.9 \\
\hline & & Mean & & & 64.7 & 93.1 & 28.4 & 113.1 & 183.15 & 78.9 \\
\hline & \multirow{4}{*}{ Yuzaomian-9110 } & P0 & $\mathrm{W}=4529 /\left(1+1785 \mathrm{e}^{-0.095 \mathrm{t}}\right)$ & $0.9692 * *$ & 64.7 & 92.3 & 27.6 & 65.2 & 108.07 & 78.5 \\
\hline & & $\mathrm{P} 1$ & $\mathrm{~W}=6271 /\left(1+1545 \mathrm{e}^{-0.10 \mathrm{t}}\right)$ & $0.9892 * *$ & 63.4 & 91.1 & 27.7 & 89.7 & 149.02 & 77.3 \\
\hline & & P2 & $\mathrm{W}=7588 /\left(1+1993 \mathrm{e}^{-0.10 \mathrm{t}}\right)$ & $0.9935^{* *}$ & 61.9 & 87.8 & 25.9 & 109.1 & 192.56 & 74.9 \\
\hline & & Mean & & & 63.3 & 90.4 & 27.1 & 88.0 & 149.88 & 76.9 \\
\hline
\end{tabular}

The treatments $\mathrm{P} 0$, $\mathrm{P} 1$, and $\mathrm{P} 2$ represent the $\mathrm{P}$ levels, i.e., 0,100 , and $200 \mathrm{~kg} \mathrm{P}_{2} \mathrm{O}_{5}$ ha $^{-1}$. ${ }^{* *}$ represents highly significant. 
Table 6. Total N, P, K, and biomass percentage allocation in reproductive organ for Lu-54 and Yuzaomian-9110 in 2017 and 2018.

\begin{tabular}{ccccccccc}
\hline \multirow{2}{*}{ P Levels (kg ha $^{-1}$ ) } & \multicolumn{9}{c}{$\mathbf{2 0 1 7}$} & \multicolumn{5}{c}{$\mathbf{2 0 1 8}$} \\
\cline { 2 - 8 } & RNR $^{\mathbf{1}}$ (\%) & RPR (\%) & RKR (\%) & RBR (\%) & RNR (\%) & RPR (\%) & RKR (\%) & RBR (\%) \\
\hline Lu-54 & & & & & & & & \\
P0 & $50.6 \mathrm{~b}^{2}$ & 51.2 & 44.6 & 59.0 & 49.9 & 54.8 & 47.5 & $66.2 \mathrm{abc}$ \\
P1 & $51.2 \mathrm{ab}$ & 51.6 & 46.1 & 56.5 & 50.4 & 53.7 & 46.9 & $69.9 \mathrm{a}$ \\
P2 & $52.9 \mathrm{a}$ & 53.2 & 46.4 & 58.4 & 51.4 & 54.2 & 47.2 & $67.6 \mathrm{ab}$ \\
Mean & 51.6 & 52.0 & 45.7 & 58.0 & 50.6 & 54.2 & 47.2 & 67.9 \\
\hline Yuzaomian-9110 & & & & & & & & \\
P0 & $49.3 \mathrm{~b}$ & 52.9 & 46.4 & 58.4 & 51.4 & 54.0 & 46.1 & $61.6 \mathrm{~d}$ \\
P1 & $51.6 \mathrm{ab}$ & 53.8 & 46.6 & 56.7 & 50.1 & 54.6 & 46.9 & $63.6 \mathrm{~cd}$ \\
P2 & $53.4 \mathrm{a}$ & 54.8 & 46.3 & 56.0 & 52.1 & 53.7 & 47.5 & $64.0 \mathrm{bcd}$ \\
Mean & 51.4 & 53.8 & 46.4 & 57.1 & 51.2 & 54.1 & 46.8 & 63.1 \\
\hline Significance of factors & & & & & & & & \\
Variety & NS & NS & NS & NS & NS & NS & NS & $*$ \\
P levels & $* *$ & NS & $* *$ & NS & NS & NS & NS & NS \\
Variety $\times$ P level & NS & NS & NS & NS & NS & NS & NS & NS \\
\hline
\end{tabular}

${ }^{1}$ RNR: the percentage of total $\mathrm{N}$ in reproductive organ; RPR: the percentage of total $\mathrm{P}$ in reproductive organ; RKR: the percentage of total $\mathrm{K}$ in reproductive organ; RBR: the percentage of biomass in reproductive organ. ${ }^{2}$ For each cultivar, values followed by a different letter within the same column are significantly different at $p<0.05$ probability level. Each value represents the mean of three replications. ${ }^{3}$ NS means non-significant. ${ }^{* *}$ Indicates significant difference at $p<0.01$ probability level. The treatments $\mathrm{P} 0$, $\mathrm{P} 1$, and $\mathrm{P} 2$ represent the $\mathrm{P}$ levels i.e., 0,100 , and $200 \mathrm{P}_{2} \mathrm{O}_{5}$ $\mathrm{kg} \mathrm{ha}^{-1}$.

\subsection{Inter-Trait Relationship}

The RO biomass, $\mathrm{N}$, and $\mathrm{K}$ content showed a positively linear relationship with the $\mathrm{P}$ content accumulated in the organ. However, the slope of the fitted line varied for biomass $\left(R^{2}=0.9064-0.9021\right)$, $\mathrm{N}$ content $\left(R^{2}=0.9430-0.9474\right)$, and $\mathrm{K}$ content $\left(R^{2}=0.9081-0.9261\right)$ in 2017 and 2018 respectively, as presented in Figure 7a-c. Similarly, the N, P, K, and biomass accumulation in the RO showed a positive correlation between each other (Figure 8), but the strength of this correlation varied between 2017 and 2018 cropping seasons. 


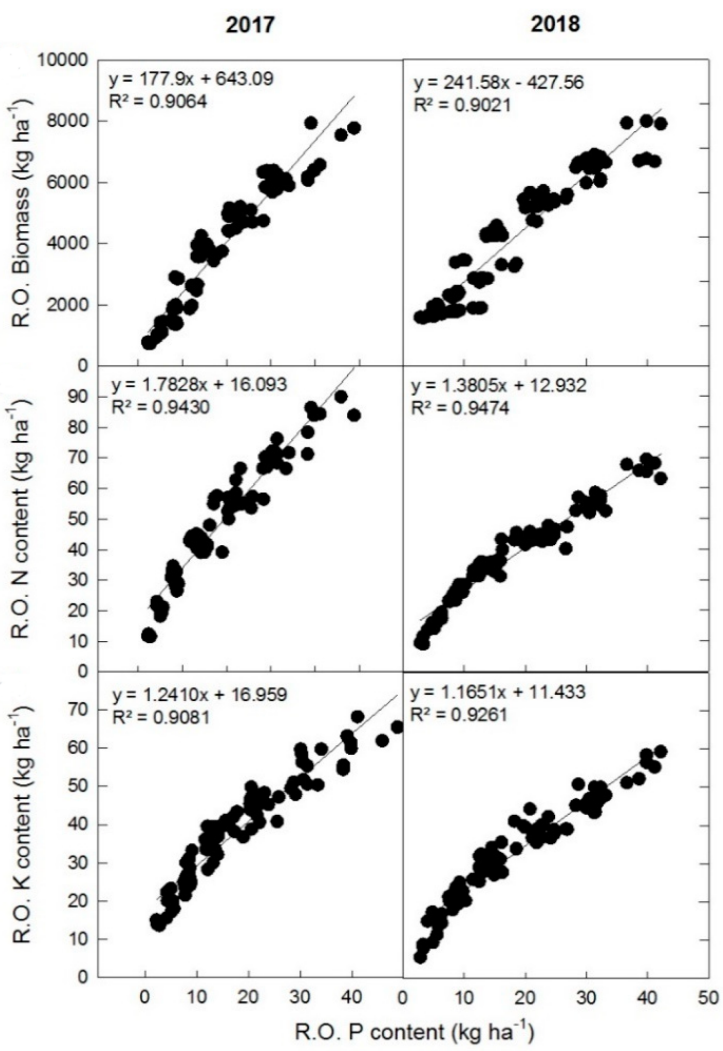

Figure 7. Relationship between accumulation of N, P, K, and biomass during 2017 and 2018 cropping seasons.

2017

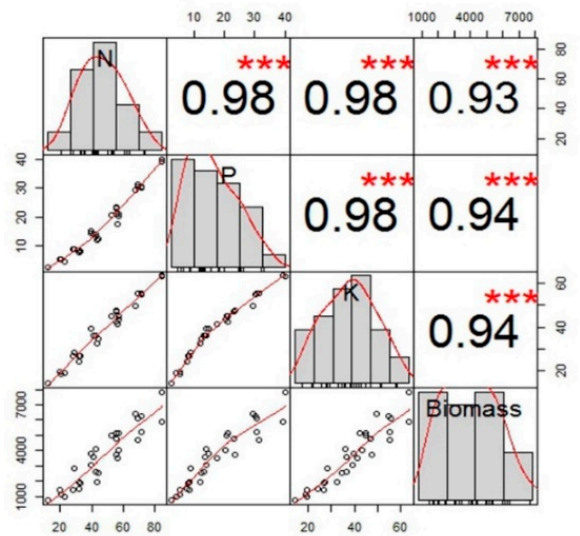

2018

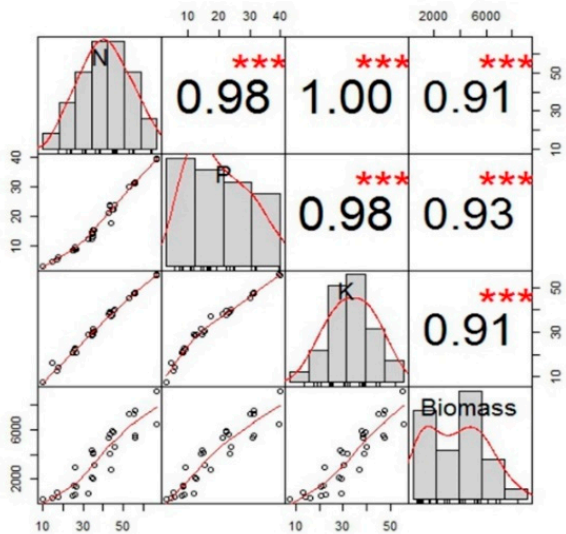

Figure 8. Correlation between N, P, K, and reproductive organ biomass during 2017 and 2018 cropping seasons. The bars and line, shown with observation, are regarded as correlation coefficients as 1 ( $R=$ 1 ). Other line graphs and correlation coefficients represent the comparative values to $R=1$. Where *** showed very highly significant $(p \leq 0.001)$.

\section{Discussion}

The present study was based on the effect of different $\mathrm{P}$ application rates on biomass and nutrients accumulation in $\mathrm{RO}$ of two cotton cultivars differing in P sensitivity. In the present study, P application had a significant effect on nutrients (N, P, and K) and biomass accumulation in the RO. Both cotton cultivars significantly varied for the aforementioned parameters during 2017 and 2018. This change in nutrients' accumulation might be due to a good balance between N, P, and K contents in the soil, resulting in a higher uptake of the nutrients by the roots. Similarly, higher P application treatments 
might increase the available P contents in the soil, leading to a well-established transport of water and nutrients towards the areal parts of the plant. These results are in line with the findings of Widowati et al. [28], who found that the proper and balanced inorganic nutrients promoted the fertility of the soil which enhanced the crop productivity. The availability of proper nutrients to the cotton plants might help in leaf growth and development followed by its proper functions with the application of P1 and P2 over the control. Li et al. [23] also reported similar results that a good nutrients balance improved the crop growth. In the present study, cotton cultivars showed a different behavior regarding nutrient uptake that might be due to their sensitivity and tolerance to $\mathrm{P}$ deficiency. The patterns of N, P, and K were similar with a slight change between two growing seasons. The increase in the nutrients at early $39 \mathrm{DAT}$, which reached to a peak at $83 \mathrm{DAT}$, was consistent. The possible reason for the trend might be that the plant demand for NPK was higher at later stages. These results are in a good agreement with the findings of Yang et al. [29] and Hu et al. [30]. The difference of NPK in the RO of different treatments was due to different levels of P supply from the soil to plants. Furthermore, higher P content in plant $\mathrm{RO}$ helped to improve the $\mathrm{N}$ and $\mathrm{K}$, and a similar phenomenon was recorded in the present study (Figure $7 \mathrm{~b}, \mathrm{c}$ ). The improved N, P, and $\mathrm{K}$ contents are also linked to the RO biomass; hence, it enhanced the boll biomass in the present study (Figure 7a). However, two cotton growing seasons (2017 and 2018) showed a slight variation that might be due to the difference of weather conditions during both years (Figure 1). Alterations in the nutrient application and weather conditions changed the nutrient accumulation, speed, initiation, and termination time during the fast accumulation period (FAP) and significantly affected the yield of cotton [31].

In cotton, RO biomass is considered as one of the most important factors directly influencing the yield. In the present study, the cultivar differences in $P$ utilization showed a significant change in the RO biomass accumulation, which might create the yield difference (Figure 2). The RO biomass attained a peak at 83 DAT with a clear difference in P application treatments (Figure 6). After 83 DAT, the RO biomass did not change because at this stage, bolls reached near to a maturation stage. This biomass increase with the increase in $\mathrm{P}$ application might be attributed to the higher $\mathrm{P}$ supply that favored the nutrients ( $\mathrm{N}$ and $\mathrm{K}$ ) and photosynthates translocation toward the reproductive part rather than vegetative organs. These finding are in accord with the conclusion of Cao et al. [32] and Stewart et al. [33], that $\mathrm{P}$ application restricts the photoassimilates' translocation from vegetative organs and is increasingly directed towards the RO. Singh et al. [34] concluded that the accumulation of dry matter was higher due to better photosynthesis, which resulted in a better supply of photosynthates and assimilates to the fruit. In the present study, higher biomass accumulation was recorded in the $\mathrm{RO}$ of the cotton in Lu-54 during 2018 compared to Yuzaomian-9110 (Figure 6). These findings were similar to previous results presented by Wang et al. [35], that dry matter accumulation was different in different cotton cultivars with different partitioning to vegetative and reproductive parts. The main reason behind this phenomenon was that the $\mathrm{P}$ application might increase the $\mathrm{N}, \mathrm{P}$, and $\mathrm{K}$ contents in leaf and other parts which influence the nutrients' availability to the plants, establishing a better source-sink relationship. A well-established source-sink balance guarantees the better RO development, resulting in an increase in final yield [36].

The accumulation of nutrients in cotton plant parts and its distribution to the sink play a vital role in the production of seed cotton yield. In the present study, nutrients (N, P, and $\mathrm{K})$ and biomass in cotton RO significantly increased with the $\mathrm{P}$ application and advancement of growth stages at higher speed compared to the control (Table 2, Table 3, Table 4, and Table 5). These results might be due to the proper P nutrient application which increased the $\mathrm{N}, \mathrm{P}, \mathrm{K}$, and biomass accumulation average maximum speed $\left(\mathrm{V}_{\mathrm{M}}\right)$ and average speed $\left(\mathrm{V}_{\mathrm{T}}\right)$ during the FAP. A similar result was stated by Tung et al. [31] and Yang et al. [37], that the fluctuation in the nutrient application and rate along with management practices in cotton affected the accumulation of different nutrients and its speed to the RO.

The $\mathrm{N}$ and $\mathrm{K}$ are the highly absorbable nutrients in soil compared with the $\mathrm{P}$ [38]. However, $\mathrm{P}$ availability influenced the accumulation of $\mathrm{N}$ and $\mathrm{K}$ in the plants by increasing the pool of ATP [39]. 
The current study revealed a higher accumulation of $\mathrm{N}$ and $\mathrm{K}$ in the $\mathrm{RO}$ of cotton in the $\mathrm{P} 2$ treatment in Lu-54 during 2017 compared to the cultivar Yuzaomian-9110 (Figures 3 and 5). Similarly, the average speed $\left(\mathrm{V}_{\mathrm{T}}\right)$ at FAP was observed to be higher at P2 treatment in Lu-54 during 2017 compared to other treatments (Tables 2 and 4). These results might be due to the availability and accumulation of $\mathrm{N}$ and $\mathrm{K}$ from the soil in the presence of a higher application of $\mathrm{P}$ compared to the control, which enhanced the performance of cultivar to respond better to $P$ fertilizer. Similarly, the results presented by Yang et al. [37] revealed that increases in yield occurred with higher inorganic fertilizer, which could be interlinked with the extended growing season by promoting the growth period of cotton by getting more P compared to the control. The current results are also in line with the finding of Gebaly et al. [40], who reported that cotton accumulated a high rate of $\mathrm{K}$ from the soil. Plenty of studies have reported that cotton cultivars showed different variations in partitioning of dry matter between vegetative and reproductive parts [27,41-43]. Cultivars with a greater dry matter partitioning ability to their reproductive parts are usually considered as efficient in increasing seed cotton yield.

The P accumulation in cotton resulted higher in Lu-54 at P2 treatment at 99 DAT during 2017 compared to the control (Figure 4), which improved the biomass of $\mathrm{RO}$ and resulted in a higher yield. This might be due to the better availability of $\mathrm{P}$ and mobility of photoassimilates to RO of cotton with the advancement of growth stages. Similarly, increased P uptake improved the plants' growth and resulted in increased yield in other crops, such as maize [44]. In the current study, P application promoted the average speed $\left(\mathrm{V}_{\mathrm{T}}\right)$ and average maximum speed $\left(\mathrm{V}_{\mathrm{M}}\right)$ of $\mathrm{P}$ accumulated in Lu- 54 during 2017 compared to Yuzaomian-9110 in the RO of cotton (Table 3), which might be due to the better availability of $P$ nutrients and unexpected weather condition to prolong the growing period of cotton. Similarly, uptake of $\mathrm{P}$ and its distribution to the cotton boll resulted in a higher increase in boll biomass (Table 5), with higher $\mathrm{V}_{\mathrm{T}}$ and $\mathrm{V}_{\mathrm{M}}$ [45]. However, Gill et al. [46] reported that $\mathrm{P}$ deficiency promoted dry matter accumulation in cotton, which might be due to different soil and climatic conditions as well as difference of cultivar P sensitivity. Nitrogen and $\mathrm{K}$ concentration in the $\mathrm{RO}$ remained higher compared with the control because these nutrients are easily taken up by the plants. Similar results were reported by Blom-Zandstra et al. [47] and Hsiao et al. [48], showing that the concentration of $\mathrm{N}$ and $\mathrm{K}$ remained the same due to their ionic solution forms that played a pivotal role in osmotic adjustment. Further, P-deficient conditions resulted in a stagnate growth and increased the P level in petiole sap. On other hand, $\mathrm{P}$ application improved nutrients' concentration and biomass in the plants, leading to an increase in reproductive growth, such as improving flowerings [49] and to extend the growing season of cotton [36,37]. The P deficiency strongly constrains the translocation of nutrients; however, it mainly affects the biomass because cotton growth responded highly to ambient weather, better supply of nutrients, and availability of water in the soil $[50,51]$. This leads to a better equilibrium among vegetative and reproductive growth by supplying a higher $P$ to establish a good and balanced source-sink relationship.

Nutrients are still limiting factors in agro-ecosystem, although human activities increased N, $\mathrm{P}, \mathrm{K}[52-54]$, and micronutrients $[55,56]$. In the present study, the boll biomass, by the combined effect of all the three major nutrients, increased with the combination of $\mathrm{N}, \mathrm{P}$, and $\mathrm{K}$, especially under P1 and P2 application in Lu-54 compared to Yuzaomian-9110 during the 2018 growing season (Figure 6). Initiation and termination days for biomass accumulation changed with the application of $\mathrm{P}$, while $\mathrm{V}_{\mathrm{M}}$ and $\mathrm{V}_{\mathrm{T}}$ were increased with the application of $\mathrm{P} 2$ compared to the control in both the cultivars (Table 5). The percent allocation of $\mathrm{N}$ and $\mathrm{K}$ varied significantly with the application of P; however, the cultivar was not significantly affected in 2017 (Table 6). Contrary to this, for the $\mathrm{P}$ and biomass allocation in 2017, while N, P, and K allocation in 2018 did not vary significantly in both cultivars and $\mathrm{P}$ application, the biomass, however, was significantly affected by cultivars and showed no effect with the P application (Table 6). These results might be due to the synergistic effect of nutrients which increased the biomass and alternately affected the yield of cotton. Opposite to the $P$ deficiency, the higher rate of $\mathrm{P}$ application negatively affected the biomass of $\mathrm{RO}$ in cotton [23]. This reduction is due to a disturbance in the source-sink relationship under P imbalance [57]. Marshner 
and Rengel [58] reported synergistic effects of major nutrients on cotton boll biomass. On the other hand, Zahreddine et al. [59] reported that the exceeded nutrients' concentration from optimal, reduced the biomass production. Extension in the growing period occurred due to a loss of fruiting structures, which resulted in leaf expansion, photosynthetic capacity, and increased carbon assimilation [60-62]. The photoassimilates were accumulated with the continued growth period, with a better supply, rate, and quantity of nutrient accumulation with differed growth periods [63]. Crops benefited from the fast $\mathrm{N}$ uptake during initial to peak flowering stage. Cotton yield and growth were strongly affected by uptake of nutrients and its speed at FAP [64]. Many reports, including Jenkins et al. [65], assumed that the change from vegetative to reproductive growth was earlier in new cultivars. Various studies also reported a different response of cultivars in biomass production and dry matter partitioning between vegetative and reproductive growth $[63,66,67]$. Due to indeterminate growth of cotton, the nutrients' deposition varies with the time and with the advancement of growth stages. A higher and faster accumulation of nutrients in the $\mathrm{RO}$ of cotton with higher biomass accumulation occurs. Nutrient accumulation and biomass production in $\mathrm{RO}$ of cotton data would be useful for growers to take management decisions for maximizing the seed cotton yield.

\section{Conclusions}

The present study evaluated the response of two cotton cultivars with different P sensitivity to $\mathrm{P}$ application. The results concluded that: higher accumulation of nutrients was reported in Lu-54 compared to Yuzaomian-9110. Higher total N, P, and K accumulation was found with the incorporation of high P level at 83 DAT, and then remained constant at 99 DAT in both used cultivars during 2017 and 2018, respectively. Higher nutrient accumulation was recorded in total $\mathrm{N}$ and $\mathrm{K}$ forms while $\mathrm{P}$ remained lower in all parts of the reproductive organ of cotton cultivars. Total biomass accumulation was recorded higher at 83 DAT and remained stable until 99 DAT in response to P application. Cotton cultivar Lu-54 produced higher reproductive organ biomass as compared with the Yuzaomian-9110. The increment in seed cotton yield was associated with higher N, P, K, and RO biomass. Conclusively, $200 \mathrm{~kg} \mathrm{P}_{2} \mathrm{O}_{5} \mathrm{ha}^{-1}$ (P2) application could be a sufficient level with a boll opening stage at 99 DAT for the better yield performance in Lu-54 compared to Yuzaomian-9110.

Author Contributions: Data curation and writing—original draft, B.I.; investigation, F.K., H.L., J.W., and W.A.K.; writing-review and editing, I.U. and S.A.; conceptualization and supervision, Z.Z. All authors have read and agreed to the published version of the manuscript.

Funding: This research was funded by the National Key Research and Development Program of China (2017YFD0201900), China Agriculture Research System (CARS-15-14) and Jiangsu Collaborative Innovation Center for Modern Crop Production (JCIC-MCP). The APC was funded by Z.Z.

Conflicts of Interest: There are no conflicts of interest to declare.

\section{References}

1. Constable, G.A.; Bange, M.P. The yield potential of cotton (Gossypium hirsutum L.). Field Crops Res. 2015, 182, 98-106. [CrossRef]

2. Saleem, M.; Maqsood, M.; Javaid, A.; Hassan, M.; Khaliq, T. Optimum irrigation and integrated nutrition improves the crop growth and net assimilation rate of cotton (Gossipium hirsutum L.). Pak. J. Bot. 2010, 42, 3659-3669.

3. Mao, S.C. Cotton Farming in China Shanghai; Shanghai Scientific and Technical Press: Shanghai, China, 2013; pp. 66-91. (In Chinese)

4. Dai, J.; Dong, H. Intensive cotton farming technologies in China: Achievements, challenges and countermeasures. Field Crops Res. 2014, 155, 99-110. [CrossRef]

5. USDA. United States Department of Agriculture 2013 Cotton: World Markets and Trade. Available online: https://www.fas.usda.gov/data/cotton-world-markets-and-trade (accessed on 14 October 2016).

6. Sarkar, B.; Patra, A.K.; Purakayastha, T.J. Transgenic Bt-Cotton Affects Enzyme Activity and Nutrient Availability in a Sub-Tropical Inceptisol. J. Agron. Crop Sci. 2008, 194, 289-296. [CrossRef] 
7. Yang, G.; Jiao, L.X.; Chun, N.Y.; Long, Z.X. Effects of Plant Density on Yield and canopy micro environment in hybrid cotton. J. Integr. Agric. 2014, 13, 2154-2163. [CrossRef]

8. Wang, Y.; Li, X.L. Progress in adaptive mechanisms of different genotypic plants to low phosphorus stress. Eco-Agr. Res. 2000, 8, 34-36.

9. Geisseler, D.; Scow, K.M. Long-term effects of mineral fertilizers on soil microorganisms-A review. Soil Biol. Biochem. 2014, 75, 54-63. [CrossRef]

10. Parfitt, R.L.; Baisden, W.T.; Elliott, A.H. Phosphorus inputs and outputs for New Zealand in 2001 at national and regional scales. J. R. Soc. N. Z. 2008, 38, 37-50. [CrossRef]

11. Gilbert, N. The disappearing nutrient. Nature 2009, 461, 716-718. [CrossRef] [PubMed]

12. Lynch, J.P. Root phenes for enhanced soil exploration and phosphorus acquisition: Tools for future crops. Plant Physiol. 2011, 156, 1041-1049. [CrossRef]

13. Mai, W.; Xue, X.; Gu, F.; Rong, Y.; Tian, C. Can optimization of phosphorus input lead to high productivity and high phosphorus use efficiency of cotton through maximization of root/mycorrhizal efficiency in phosphorus acquisition? Field Crops Res. 2018, 216, 100-108. [CrossRef]

14. Vance, C.P.; Uhde-Stone, C.; Allan, D.L. Phosphorus acquisition and use: critical adaptations by plants for securing a nonrenewable resource. New Phytol. 2003, 157, 423-447. [CrossRef]

15. Singh, V.; Pallaghy, C.K.; Singh, D. Phosphorus nutrition and tolerance of cotton to water stress: I. Seed cotton yield and leaf morphology. Field Crops Res. 2006, 96, 191-198. [CrossRef]

16. Girma, K.; Teal, R.K.; Freeman, K.W.; Boman, R.K.; Raun, W.R. Cotton lint yield and quality as affected by applications of N, P, and K fertilizers. J. Cotton Sci. 2007, 11, 12-19.

17. Roy, R.N. Integrated plant nutrition systems-Conceptual overview. In Proceedings of symposium on "Integrated plant nutrition management"; National Fertilizer Development Center: Islamabad, Pakistan, 2000; pp. 45-48.

18. Unruh, B.L.; Silvertooth, J.C. Comparison between upland and a Pima cotton cultivars II. Nutrient uptake and partitioning. Agron. J. 1996, 88, 589-595. [CrossRef]

19. Sawan, Z.M. Mineral fertilizers and plant growth retardants: Its effects on cottonseed yield; its quality and contents. Cogent Biol. 2018, 4, 1459010. [CrossRef]

20. Gebaly, S.G.; El-Gabiery, A.E. Response of cotton Giza 86 to foliar application of phosphorus and mepiquat chloride under fertile soil condition. J. Agric. Res. 2012, 90, 191-205.

21. Wang, J.; Chen, Y.; Wang, P.; Li, Y.S.; Wang, G.; Liu, P.; Khan, A. Leaf gas exchange, phosphorus uptake, growth and yield responses of cotton cultivars to different phosphorus rates. Photosynthetica 2018, 56, 1414-1421. [CrossRef]

22. Luo, H.H.; Zhang, Y.L.; Zhang, W.F. Effects of water stress and rewatering on photosynthesis, root activity, and yield of cotton with drip irrigation under mulch. Photosynthetica 2016, 54, 65-73. [CrossRef]

23. Li, H.G.; Huang, G.; Meng, Q.; Ma, L.; Yuan, L.X.; Wang, F.; Zhang, W.; Cui, Z.L.; Shen, J.B.; Chen, X.P.; et al. Integrated soil and plant phosphorus management for crop and environment in China. A review. Plant Soil 2011, 349, 157-167. [CrossRef]

24. Yang, H.; Meng, Y.; Chen, B.; Zhang, X.; Wang, Y.; Zhao, W. How integrated management strategies promote protein quality of cotton embryos: High levels of soil available $\mathrm{N}, \mathrm{N}$ assimilation and protein accumulation rate. Front. Plant Sci. 2016, 7, 1118. [CrossRef] [PubMed]

25. Li, H.J.; Wang, J.; Saif, A.; Babar, I.; He, Z.; Shanshan, W.; Binglin, C.; Zhiguo, Z. Agronomic traits at the seedling stage, yield and fiber quality in two cotton (Gossypium hirsutum L.) cultivars in response to phosphorus deficiency. Soil Sci. Plant Nutr. 2019. [CrossRef]

26. Baker, D.A.; Young, D.L.; Huggins, D.R.; Pan, W.L. Economically optimal nitrogen fertilization for yield and protein in hard red spring wheat. Agron. J. 2004, 96, 116-123. [CrossRef]

27. Yang, G.; Tang, H.; Nie, Y.; Zhang, X. Responses of cotton growth, yield, and biomass to nitrogen split application ratio. Eur. J. Agron. 2011, 35, 164-170. [CrossRef]

28. Widowati, I.; Utomo, W.; Guritno, B.; Soehono, L. The effect of biochar on the growth and $\mathrm{N}$ fertilizer requirement of maize (Zea mays L) in greenhouse experiment. J. Agric. Sci. 2012, 4, 255-262.

29. Yang, M.H.; Jiang, Y.J.; Nie, W.L.; Zheng, D.M. Effect of phosphorus application on accumulating dynamic change of nitrogen, phosphorus and potassium nutrient of the hybrid cotton. Xinjiang Agric. Sci. 2010, 47, 1172-1177. (In Chinese) 
30. Hu, W.; Nan, J.; Jiashuo, Y.; Yali, M.; Youhua, W.; Binglin, C.; Wenqing, Z.; Derrick, M.O.; Zhiguo, Z. Potassium (K) supply affects $\mathrm{K}$ accumulation and photosynthetic physiology in two cotton (Gossypium hirsutum L.) cultivars with different K sensitivities. Field Crops Res. 2016, 196, 51-63. [CrossRef]

31. Tung, S.A.; Huang, Y.; Hafeez, A.; Ali, S.; Khan, A.; Souliyanonh, B.; Song, X.; Liu, A.; Guozheng, Y. Mepiquat chloride effects on cotton yield and biomass accumulation under late sowing and high density. Field Crops Res. 2018, 215, 59-65. [CrossRef]

32. Cao, Y.; He, J.; Yan, Y.; Feng, Z.; Wang, Q.; Zhang, Y. Effect of water deficit on cotton characteristics. China Cotton 2003, 30, 29-30, (In Chinese with English Abstract).

33. Stewart, W.M.; Reiter, J.S.; Krieg, D.R. Cotton response to multiple application of phosphorus fertilizer. Better Crops Plant Food. 2005, 89, 18-20.

34. Singh, S.K.; Reddy, V.R.; Fleisher, D.H.; Timlin, D.J. Growth, nutrient dynamics, and efficiency responses to carbon dioxide and phosphorus nutrition in soybean. J. Plant Interact. 2014, 9, 838-849. [CrossRef]

35. Wang, S.; Han, X.; Yan, J.; Xiao, L.I.; Qiao, Y. Impact of phosphorus deficiency stress on root morphology, nitrogen concentration and phosphorus accumulation of soybean (Glycine max L.). China J. Soil Sci. 2010, 41, 644-650.

36. Saleem, M.F.; Shakeel, A.; Bilal, M.F.; Shahid, M.Q.; Anjum, S.A. Effect of different phosphorus levels on earliness and yield of cotton cultivars. Soil Environ. 2010, 29, 128-135.

37. Yang, G.; Tang, H.; Tong, J.; Nie, Y.; Zhang, X. Effect of fertilization frequency on cotton yield and biomass accumulation. Field Crops Res. 2012, 125, 161-166. [CrossRef]

38. Zhu, J.; Li, M.; Whelan, M. Phosphorus activators contribute to legacy phosphorus availability in agricultural soils: A review. Sci. Total Environ. 2018, 612, 512-537. [CrossRef]

39. Gautam, P.; Gustafson, D.M.; Wicks, Z. Phosphorus concentration, uptake and dry matter yield of corn hybrids. World J. Agric. Sci. 2011, 7, 418-424.

40. Gebaly, S.G. Physiological effects of potassium forms and methods of application on cotton variety Giza 80 . Egypt. J. Agric. Res. 2012, 90, 1633-1646.

41. Meredith, W.R., Jr.; Wells, R. Potential for increasing cotton yields through enhanced partitioning to reproductive structures. Crop Sci. 1989, 29, 636-639. [CrossRef]

42. Unruh, B.L.; Silvertooth, J.C. Comparison between upland and a Pima cotton cultivar. I. Growth and yield. Agron. J. 1996, 88, 583-589. [CrossRef]

43. Mao, L.; Zhang, L.; Zhao, X.; Liu, S.; van der Werf, W.; Zhang, S.; Li, Z. Crop growth, light utilization and yield of relay intercropped cotton as affected by plant density and a plant growth regulator. Field Crops Res. 2014, 155, 67-76. [CrossRef]

44. Ma, Q.H.; Zhang, F.S.; Rengel, Z.; Shen, J.B. Localized application of $\mathrm{NH}_{4}{ }^{+}-\mathrm{N}$ plus $\mathrm{P}$ at the seedling and later growth stages enhances nutrient uptake and maize yield by inducing lateral root proliferation. Plant Soil 2013, 372, 65-80. [CrossRef]

45. Wang, X.X.; Liu, S.; Zhang, S.; Li, H.; Maimaitiaili, B.; Feng, G.; Rengel, Z. Localized ammonium and phosphorus fertilization can improve cotton lint yield by decreasing rhizosphere soil $\mathrm{pH}$ and salinity. Field Crops Res. 2018, 217, 75-81. [CrossRef]

46. Gill, M.A.; Sabir, M.; Ashraf, S.; Rahmatullah, A.T. Effect of P-stress on growth, phosphorus uptake and utilization efficiency of different cotton cultivars. Pak. J. Agric. Sci. 2005, 42, 42-47.

47. Blom-Zandstra, M.; Lampe, J.E.M. The effect of chloride and sulpate salts on nitrate content in lettuce plants (Lactuca satica L.). J. Plant Nutr. 1983, 6, 611-628. [CrossRef]

48. Hsiao, T.C.; Lauchli, L. Role of potassium in plant water relations. In Advances in Plant Nutrition; Tinker, P.B., Lauchli, A., Eds.; Praeger: New York, NY, USA, 1986; Volume 2, pp. 281-382.

49. Biles, S.P.; Cothren, J.T. Flowering and yield response of cotton to application of mepiquat chloride and PGR-IV. Crop Sci. 2001, 41, 1834-1837. [CrossRef]

50. Xu, X.; Taylor, H.M. Increase in drought resistance of cotton seedlings treated with mepiquat chloride. Agron. J. 1992, 84, 569-574. [CrossRef]

51. Song, C.J.; Ma, K.M.; Qu, L.Y.; Liu, Y.; Xu, X.L.; Fu, B.J.; Zhong, J.F. Interactive effects of water, nitrogen and phosphorus on the growth, biomass partitioning and water-use efficiency of Bauhinia faberi seedlings. J. Arid Environ. 2010, 74, 1003-1012. [CrossRef]

52. Sardans, J.; Rodà, F.; Peñuelas, J. Effects of water and a nutrient pulse supply on Rosmarinus officinalis growth, nutrient content and flowering in the field. Environ. Exp. Bot. 2005, 53, 1-11. [CrossRef] 
53. Sardans, J.; Peñuelas, J.; Rodà, F. Changes in nutrient status, retranslocation and use efficiency in young post-fire regeneration Pinus halepensis in response to sudden $\mathrm{N}$ and $\mathrm{P}$ input, irrigation and removal of competing vegetation. Trees 2005, 19, 233-250. [CrossRef]

54. Makhdum, M.I.; Pervez, H.; Ashraf, M. Dry matter accumulation and partitioning in cotton (Gossypium hirsutum L.) as influenced by potassium fertilization. Biol. Fertil. Soils 2007, 43, 295-301. [CrossRef]

55. Kidron, G.J.; Zilberman, A. Low cotton yield is associated with micronutrient deficiency in West Africa. Agron. J. 2019, 111, 1977-1984. [CrossRef]

56. Lambrecht, I.; Vanlauwe, B.; Maertens, M. Integrated soil fertility management: From concept to practice in eastern DR Congo. Int. J. Agric. Sustain. 2016, 14, 100-118. [CrossRef]

57. Rosolem, C.A.; Oosterhuis, D.M.; Souza, F.S.D. Cotton response to mepiquat chloride and temperature. Sci. Agric. 2013, 70, 82-87. [CrossRef]

58. Marshner, P.; Rengel, Z. Plant-Soil Relationships. In Mineral Nutrition, Yield and Source-Sink Relationships, 3rd ed.; Academic Press: Orlando, FL, USA, 2012.

59. Zahreddine, H.G.; Struve, D.K.; Talhouk, S.N. Growth and nutrient partitioning of containerized Cercis siliquastrum L. under two fertilizer regimes. Sci. Hortic. 2007, 112, 80-88. [CrossRef]

60. Dong, H.Z.; Tang, W.; Li, W.J.; Li, Z.H.; Niu, Y.H.; Zhang, D.M. Yield, leaf senescence, and Cry1Ac expression in response to removal of early fruiting branches in transgenic Bt cotton. Agric. Sci. China 2008, 7, 692-702. [CrossRef]

61. Lu, B.Q.; Downes, S.; Wilson, L.; Gregg, P.; Knight, K.; Kauter, G.; McCorkell, B. Yield, development and quality response of dual-toxin Bt-cotton to manual simulation of damage by Helicoverpa spp. in Australia. Crop Prot. 2012, 41, 24-29. [CrossRef]

62. Wells, R. Leaf pigment and canopy photosynthetic response to early flower removal in cotton. Crop Sci. 2001, 41, 1522-1529. [CrossRef]

63. Gao, Y.; Lynch, J.P. Reduced crown root number improves water acquisition under water deficit stress in maize (Zea mays L.). J. Exp. Bot. 2016, 67, 4545-4557. [CrossRef]

64. Bange, M.P.; Milroy, S.P.; Thongbai, P. Growth and yield of cotton in response to waterlogging. Field Crops Res. 2004, 88, 129-142. [CrossRef]

65. Jenkins, J.N.; McCarty, J.C., Jr.; Parrott, W.L. Effectiveness of fruiting sites in cotton: Yield. Crop Sci. 1990, 32, 365-369. [CrossRef]

66. Ma, Q.; Rengel, Z.; Rose, T. The effectiveness of deep placement of fertilisers is determined by crop species and edaphic conditions in Mediterranean-type environments: A review. Soil Res. 2009, 47, 19-32. [CrossRef]

67. Chen, B.L.; Sheng, J.D.; Jiang, P.A.; Liu, Y.G. Effect of applying different forms and rates of phosphoric fertilizer on phosphorus efficiency and cotton yield. Cotton Sci. 2010, 22, 49-56. 